\title{
Seismic Activity During
}

the 1968 Test Pumping at

the Rocky Mountain Arsenal

Disposal Well

By D. B. Hoover and J. A. Dietrich

GEOLOGICAL SURVEY CIRCULAR 613

This report concerns work done in cooperation with the

U.S. Army Corps of Engineers

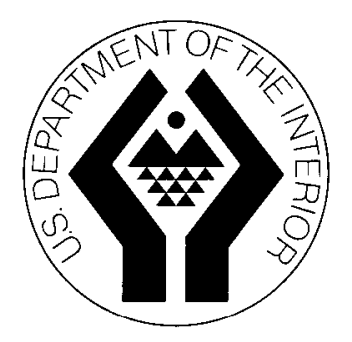

COLORADO WATER

RESOURCES LIBRARY

U.S. GEOLOGICAL SURVEY

WRD, DENVER 
United States Department of the Interior

STEWART L. UDALL, Secretary

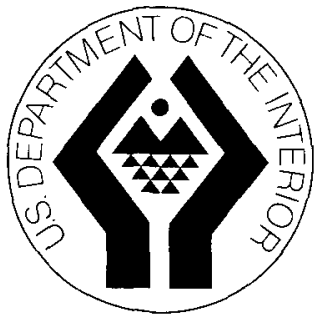

Geological Survey

William T. Pecora, Director

父

Free on application to the U.S. Geological Survey, Washington, D.C. 20242 
Abstract -

Introduction - -

Data acquisition system -

Monitoring operations -

Results of test--

Acknowledgments -

References cited

\section{LLUSTRAT I ONS}

Figure 1. Location map of seismic stations used during the test program showing the time difference for arrivals between stations STK and W1

2. Empirical relationship between magnitude and coda -...-.--

3. Computer output format for an earthquake occurring on July 18, 1968

4. 1968 6-hour seismicity data -

5. 1968 10-day average seismicity-n

6. 1968 Bergen Park 10-day average seismicity -

7. Map of earthquake epicenters for September 1968

8. Map of earthquake epicenters for Oct. 1 to Nov. 4, 1968-.....

9. Histogram showing distance of earthquakes from station W1 - -

10. Temperature logs observed in the injection disposal well on Sept. 4, 1961, and Nov. 10, 1968

TABLES

Table 1. Time of occurrence of pumping tests

2. Hypocenters for some Derby earthquakes occurring during 1967 and 1968

3. Derby earthquakes from Sept. 1 to Nov. 15, 1968 



\title{
Seismic Activity During the 1968 Test Pumping at the Rocky Mountain Arsenal Disposal Well
}

\author{
By D. B. Hoover and J. A. Dietrich
}

\begin{abstract}
A.HETEACT
During the 1968 pumping tests at the Rocky Mountain Arsenal disposal well, the U.S. Geological Survey was responsible for monitoring earthquakes occurring in the area of the arsenal and making chemical analysis of the fluids removed. Three criteria were established to suspend the pumping if anomalous earthquake activity occurred during the pumping test. Thesecriteria were based on the frequency, magnitude, and location of the local earthquakes.

The pumping program consisted of four tests which occurred between September 3 and October 26, 1968. During per i ods of pumping, earthquake activity remained within acceptable limits and no suspensions of the pumping were required. After each of the two major pumping periods an increase in the frequency of small earthquakes occurred. During the first of these two periods of high seismic activity the Geological Survey recommended a delay in the start of the next phase of the pumping until the activity subsided. Most of the earthquakes during 1968 occurred northwest of the arsenal; however, in the $21 / 2$-month period after the start of the test, a larger percent of the earthquakes occurred on the arsenal than in the previous 8 -month period. The temperature in the cooled zone at the bottom of the well was $12^{\circ} \mathrm{l}$ : warmer 2 weeks after pumping stopped than it was in January 1968. Preliminary chemical analyses indicate that very little mixing between wa ste fluids and connate water has occurred.
\end{abstract}

\section{INTRODUCTION}

In September and October 1968 the U.S. Army Corps of Engineers made a pumping test of the Rocky Mountain Arsenal disposal well. This well had been used to inject about 165 million gallons of waste fluid into Precambrian basement rock 12,000 feet below the surface of the Denver basin. Shortly after the start of injection in early 1962 small earthquakes were recorded from the vicinity of the arsenal. These earthquakes, commonly known as Derby earthquakes, have continued although injection was discontinued in 1966. Most investigators agree that the earthquakes have beentriggered by the injected fluid and a recommendation has been made (Healy and others, 1968) that part of the fluid be withdrawn in an attempt to decrease the earthquake activity. The pumping tests were designed to determine if substantial amounts of the fluid could be pumped from the disposal well.
In a memorandum of understanding dated $\mathrm{J}$ une 5 , 1968, between the U.S. Geological Survey and the Corps of Engineers, Omaha District, the Geological Survey assumed responsibility for five aspects of the test pumping program at the Rocky Mountain Arsenal disposal well. Briefly these five areas of responsibility were as follows:"

1. To establish a seismic monitoring system for use during the pumping tests.

2. To provide liaison with the Color ado School of Mines to obtain benefit from related information which that institution could provide.

3. To install a special down-hole instrument package 60 days prior to the test for useduring and after pumping.

4. To monitor the seismic activity and advise the Corps of Engineers immediately of any unusual seismic activity that might occur during the test and recommend suspension of the test if anomalous seismic activity developed.

5. To provide for fluid sample collection and selective analysis of fluids removed from the reservoir. The major emphasis under these areas of responsibility was to provide a seismic monitoring program which would assure maximum protective warning should any anomalous seismic activity occur in conjunction with the fluid removal.

The pumping tests were designed to determine if large volumes of fluid could be removed from the Rocky Mountain Arsenal disposal well and if any change in seismic activity would be caused by the fluid removal. The preponderance of opinion was that a test program, which would remove only a small part of the fluid that had been injected into the reservoir, would constitute no additional seismic hazard to Denver. However, because the test was to be conducted in a largely unknown system, wh ich had previously produced slightly damaging earthquakes, there was no way 
to guarantee the complete safety of the proposed test. The monitoring procedures and criteria for suspending the test were designed toprovide for the maximum safety of the populace of Denver. This report covers Geological Survey activities. The results of the pumping test are given in a report to the Corps of Engineers (van Poollen, 1969).

In the preparatory phases of the program, difficulties were encountered in making the special down-hole instrument package operational. These difficulties, coupled with the possibility of losing or damaging the instrument package during the test, were considered sufficient reason to abandon the plan to operate the down-hole instrument during the test. The absence of the down-hole data in no way affected the ability to evaluate the seismic hazards during the pumping program.

By agreement with the Corps of Engineers, provision was made for a temporary halt of the pumping tests on the recommendation of Geological Survey per sonnel in Denver should any anomalous seismic activity become evident. Resumption of testing could bedecided at the local level, or, if conditions warranted it, the decision would be referred to joint conferencebetween the Geological Survey and the Corps of Engineers. A recommendation to terminate the test would be subject to approval of the Director of the Geological Survey and District Engineer, Omaha District, Corps of Engineers.

On the basis of the previous earthquake activity in the Derby area in 1968, the Geological Survey established three criteria to be used for calling a temporary halt in the pumping program at the field level. These criteria were reported to the Corps of Engineers on August 12, 1968. The first $c r i t e r$ ion was based on the local seismicity. If the frequency of Derby earthquakes exceeded 10 in any consecutive 6-hour period during pumping, the pump would be shut down. The second criterion would require an immediate halt to pumping if an earthquake of magnitude 3.0 or greater should occur. Lastly, any earthquake occurring within a 1.5 mile radius of the well would be considered anomalous and again a temporary but immediate halt would be ordered.

The time intervals during which the pump was operating and the total quantity of fluid removed in each test is given in table 1. Details on these tests and the prior cleanout operations arediscussed by van Poollen (1969).

Table 1.- Time of occurrence of pumping tests

\begin{tabular}{llrr}
\hline $\begin{array}{c}\text { Test } \\
\text { No. }\end{array}$ & Time of test & $\begin{array}{c}\text { Fluid nemoved } \\
\text { (gallons) }\end{array}$ \\
\hline $1--0600$ & Sept. 3-0600 Sept. 4 & 5,838 \\
$2---2300$ Sept. 4-2300 Sept. 5 & 17,950 \\
$3--2310$ Sept. 7-1800 Sept. 13 & 142,513 \\
$:--0915$ oct 21-2230 oct. 26 & 200,919 \\
\hline
\end{tabular}

Figure 1 gives the locations of the seismometers in use dûring the test program. Twenty-one seismometers in 17 locations were used. Fourteen locations were on the arsenal arranged in an offcenter cross. Three additional stations were on the west side of the South Platte River to provide a network of stations surrounding the epicentral zone. Two of the locations, sites $\mathrm{S} 46$ and $\mathrm{E} 35$, contained both horizontal and vertical seismometers to provide data on three components of ground motion; other recording locations provided data only on vertical motion. The seismometers used were Hall-Sears type HS-10 having a 2 $\mathrm{Hz}$ natural frequency.

Data from each seismometer on the arsenal were transmitted over wire line to a central recording site in building 1706 on the arsenal. Here, all the signals were electronically amplified and recorded photographically on a CEC 5- 19 oscillographic recorder. Paper speed of the $5-119$ at 1 mm per sec (millimeter per second) provided sufficient information to monitor all channels and catalog local earthquakes. Thirteen of the 18 channels were also recorded on a modified Ampex model 300 tape transport running at 0.3 ips (inches per second). Data recorded on the magnetic tape provided sufficient time resolution for accurate Iocation of the events.

The three seismometers west of the South P latte River and one of the seismometers from the arsenal array were telemetered over telephone lines to the Denver Federal Center. At the Federal Center, data from the three off-arsenal sites were recorded on an applied magnetics tape transport running at 0.3 ips to provide added information athigh time resolution.

Because of the need for a visible on-line monitoring system during the pump test, a two-channel Geo Technical Corp. helicorder system was installed in building 25 at the Federal Center. Stations STK and W1 were recorded on this visible system during the test to provide approximate magnitudes and locations as each earthquake occurred. A helicorder paper speed of $1 \mathrm{~mm}$ per sec provided about $0.1 \mathrm{sec}$ time resolution. This visible monitoring system was installed on June 27, 1968.

The system can detect Derby earthquakes in the vicinity of the arsenal of Richter magnitude approximately -1.0 or larger. The smaller events, however, are generally not locatable because of the energy attenuation across the array and reliable arrival times are not recorded at the more distant stations.

\section{MONITORING OPERATIONS}

Because of the criteria established for temporary halt of the test, it was necessary to provide an immediate indication of the number and magnitudes of Derby earthquakes and to determine their approximate 
locations. The visible monitor provided by the helicorder system in building 25 at the rederal Center was the source of basic on-line information. Luring pumping operations a 24-hour wath was made and the record was examined by trained chservers every 5 minutes. As each Derby earthquake ocurred, the observers recorded the arrival time at ach of the two stations STK and W1, the location given by the time difference $\mathrm{tSIK}$ - tW 1 , and the approximac magnitude.

The identification of a Derby earthquake was not difficult because they have a characteristic appearance unlike most other disturbances on record. Sonic booms might occasionally be mistaken for earthquakcs, but the time difference between stations SIK and WI usually served to distinguish questionabie cvents. The timing of the individual events was tabulatod and graphed as each occurred to provide the statistic necessary to implement the first criterion for temporary halt of the test.

The duration of the coda, or time that the ground was disturbed during each earthquake, was tahulated and related directly to the magnitude. The high sensitivity of the system and its limited dynamic $r$ ange precluded the use of amplitudes to determine the magnitude from body waves over any wide range. 'To resolve this difficulty an experimentally determined relationship was used to relate the coda on the helicorder to Richter magnitude determined by the Color ado School of Mines at its Bergen Park Observatory. This method has been found to work well in the magnitude range of events recorded at Bergen Park. It is recognized that serious problems exist in extrapolating this relationship to the very small magnitude events, and the magnitudes in the range below zero should be considered approximate only. The experimentally determined relationship is illustrated in figure 2 .

Approximate epicenters were obtained by measuring the time difference between stations STK and $W 1$ and plotting the epicenter using the appropriate scale(fig. 1). These two stations are on the long axis of the active zone and most of the earthquakes occur between them. Seismic events occurring at the same time at both stations are located on the line midway between the two stations; events occurring early at Wl would be closer to the well. Earthquakes whose arrival time was 0.75 second or more early at station W1 were considered anomalous and accurate locations weredetermined as rapidly as possible from the magnetic-tape recording system.

Precise hypocenter locations were obtained by reproducing the earthquakes recorded on magnetic tape onto an expanded time base photographic record and timing each arrival to $0.01 \mathrm{sec}$. The arrival times for each event were then introduced into a computer program developed by J. P. Eaton, and a least squares fit obtained to the data. Average time residuals were less than $\pm 0.01 \mathrm{sec}$ and most residuals were within +0.03 sec. A typical output from this program is shown in figure 3 . This event occurred at 20 hours, 24 minutes, $5.35 \mathrm{sec}$ GMT on July 18, 1968.

\section{RESULTS OF T'EST}

The detailed seismicity observed in the Derby area for the period January 1 to November 15, 1968, was compiled in figure 4 . The diagram shows the number of earthquakes observed in each one-quarter-day interval throughout the year. The period of greatest activity was the last quarter of July 15,1968 , when 22 earthquakes we re observed. This relatively large number of events includes the magnitude 3.3 event at $1833 \mathrm{GMT}$ and its aftershock sequence. This is the largest Derby earthquake in 1968 . The next two largest earthquakes were a magnitude 2.9 event which occurred at 1904 GMT July 27 and a magnitude 3.2 event recorded at 1429 GMT on November 2. No large number of aftershocks were noted after these two later events. Normally Derby earthquakes of magnitude 3.0 or less do not have a noticeable aftershock sequence.

Prior to pumping, the next highest peak on the seismicicy plot occurred on May 6 when nine events occurred in 6 hours. Because of this and the otherwise generally low level of activity during the year, it was decided that 10 events in a 6 -hour period would constitute anomalous activity and justify a temporary halt in operations.

After the start of the pumping test more than 10 earthquakes were rccorded in only one 6-hour period. On November 14, in 5 hours, 14 small earthquakes occurred, none of which were larger than magnitude 1.4. These events occurred 18 days after the termination of the test and during an interval of relative quiescence.

Because the average level of activity is not readily seen on the detailed plot of figure 4 , a running 10-day average seismicity plot was prepared (fig. 5). This diagram shows thenumber of earthquakes in any 10 -day interval, starting on January 1, 1968, and plorted at the start of the interval (that is, January $1-10$ was plotted on January 1). A 10-day interval was chosen since this was the time span from the start of the pump test to termination of the first three cycles of pumping. It was felt that this might show more clearly any anomalous activity that might be associated with the pumping. A smoother function was obtained, and the activity occurring on July 15, although still very definite, $3 \mathrm{esn}$ 't represent such a marked anomaly. The two hicost levels of activity occurred on Septem her 22 and October 28 when 57 and 42 events respectively wero recorded in the 10 days following those dates. Ihese occurred 19 days and 7 days after the start of tho two major pumping cycles.

The second major phase of the test was scheduled to start in late September at about the time that the seismic activity was rising to its highest level. The Geological Survey concluded that there was a significant 
chance of having to invoke one of the stop criteria if pumping was resumed during this particularly active period; therefore, on September 20 a postponement of pumping for a period of at least 15 days or until the seismicity reached lower levels was requested. On October 17 the Corps of Engineers was informed that the activity was again normal and pumping could be resumed.

It was recognized that after June 27 , when the visible monitor system was installed, there was some bias present in the data. This bias was due to the presence of a duplicate monitoring system, which was watched by many more persons than had been involved in the earlier data acquisition process. Some additional small earthquakes were undoubtedly identified because of the intensive and repeated examination of the records. To determine if this bias was significant, the smaller earthquakes in the sequence were rejected and only the larger events were considered. This was done using the data on Derby earthquakes provided by the Colorado School of Mines Bergen Park Observatory where the lower limit of sensitivity for Derby shocks is about magnitude 1.0 . This also provided an independent estimate of the seismicity pattern that was completely independent of any bias that might be present in our instrumentation and analysis system.

The 10-day running average obtained using only the Bergen Park Observatory data is shown in figure 6. Although fewer events were recorded at Bergen Park (a maximum of seven in any 10-day period), the two seismicity plots correlate remarkably well. We believe that the bias in the later part of our seismicity data is certainly less than 10 events and probably less than 5 events per 10-day period.

Table 2 lists all of the Derby earthquakes for which reliable hypocenter locations have been obt a ined by means of the computer program. Only part of the earthquakes prior to April 1, 1968, have been located and the list for this period is incomplete. Most events occurring after April 1, 1968, that were large enough to provide good signal strength across the array have been located and are listed.

From these data, maps showing the epicenter locations of the September to November 1968 earthquakes were prepared (figs. 7 and 8). These data show that most of the events occurred in the vicinity of the flood plain of the South Piatte River northwest of the we ll, but a few also occurred at the arsenal and west of the river. The epicentral zone is similar to the zone described by Healy and others (1966). There is, however, an indication that the majority of earthquakes occurred a few kilom ters to the northwest of the major center obtained in late 1965 and eariy 1966. This northwestward migration has also been observed by Major and Simon (1968).

To compare the pattern of activity prior to the pump test with that during and immediately after, datafrom table 2 was used toprepare the histograms in figure 9. In these histograms the number of events in a given distance interval are plotted against the epicentral distance from station W1. This is approximately the distance from the well and was used for convenience since it is a statistic obtained from the computer program.

The distribution of events since September 3, 1968, is broader than that for events that were located during the preceding year and a half. Since early September, earthquakes have occurred both closer to the well (some have been east of the well) and more farther northwest of the well than in the previous 18 -month period.

The complete seismicity data from September 1 to November 15,1968 , is included in table 3 . This table contains the information obtained during the tes: from the visible monitor in building 25 . At no time during pumping operations was it necessary to invoke any of the criteria established for a temporary halt. During nonpumping intervals, a few earthqidakes occurred that appeared to be anomalously close to the wall. These events were precisely located from the array data but none occurred so close to the well that termination of the test was recommended. The magnitude 3 event on November 2 and the 14 events on November 14 occurred after termination of the test.

The thermal history of the well has been of interest because of the possibility that a thermal stress triggering mechanism may be contributing to instability in the region. The thermal regime is also of interest for correcting fluid densities in the well bore and for understanding changes in transmissibility in the fluid reservoir due to changes in temperature. The fluid tem $_{i}$ erature also places practical limitations on the rate of fluid removal by limiting the amount of pressure reduction so as not to initiate boiling in the fluid column. In January 1968, a temperature log was run in the well by the Geological Survey in which a $25^{\circ} \mathrm{C}$ temperature decrease was found in the lower 160 :ee: of hole. Total depth at that time was 12,000 feet. This temperature inversion was also confirmed in work by Ball Bros. Research Corp. in June 1968. This relatively large temperature inversion is dua to the injection of 165 mjllion gallons of cold waste fluid into the reservoir during operations from January 1962 to February 1966. Because the test pumping program was drawing hot fluids from the reservoir into the chilled region immediately around the well,we were interested in determining the amount of warming at the bottom. On November $10,1968,2$ weeks after the test was terminated, a temperature log was run by Schlumberger Well Service Company. This $\log$ is shown in figure 10 , along with the log originally run in September 1961, 2 days after the lower liner was cemented. The most recent $\log$ agrees within the measuring accuracy with the log ob:ained in January 1968, except in the region of the temperature inversion. The bottom of the hole, 11,991 feet, was found to have warmed up $12^{\circ} \mathrm{F}$; most of this was a result of the pumping.

Preliminary analysis of the fluids pumped from the well indicated that very little mixing of the injected 
waste fluid with connate water had occurred (R. L. Wershaw, written commun,, 1968). These conclusions were based principally on radium and lithium analyses. Complete results will be reported when the analyses are finished.

\section{ACKNOWLEDGMENTS}

We wish to acknowledge the cooperation and assistance of the Colorato School of Mines throughout this investigation. Particular thanks go to Maurice Major and Ruth Simon for making available some of thei $r$ Bergen Park data and for much fruitful discussion. We extend our appreciation to the Corps of Lingineers for financial support during the past years and during the test program. The valuable assistance of James Zeltinger and Lou Gustafson, Corps of Engineers representatives on site during the test, was greatly appreciated. These two individuals were of particular service to us in the fluid sampling program during their long vigils at the well site. We extend our appreciation for helpful advice and additional equipment to our Survey colleagues in Menlo Park, Calif., specifically J. P. Eaton, W. H. Jackson, and Jo'n Roller.
We would like to acknowledge the assistan 2 e of Rhoda Robinson, Penny Miller, A. C. A ustin, Don Peterson, R. F. Schoenfeld, Dolores Wilson, and Tom Davison, who conscientiously spent many hours, often late at night, peering at the slow!y revolving recording drum. To these people goes much credit for the success of the operations during the test prog ram.

\section{REFERENCES CITED}

Healy, J. H., and others, 1966, Geophysical and geological investigations relating to earthquakes in the Denver area, Colorado: U.S. Geol. Survey open-file report.

1968, The Denver earthquakes: Science, v. 161 , no. 3848 .

Major, Maurice, and Simon, Ruth, 1968, A seis ic study of the Denver [Derby] earthquakes: Colorado School of Mines Quart., v. 63, no. 1.

van Poo!len, H. K., 1969, Rocky Mountain Arsenal well pumping tests, 1968: U.S. Army Corps of Engineers, Omaha District. 

FIGURES 1-10 AND TABLES 2, 3 


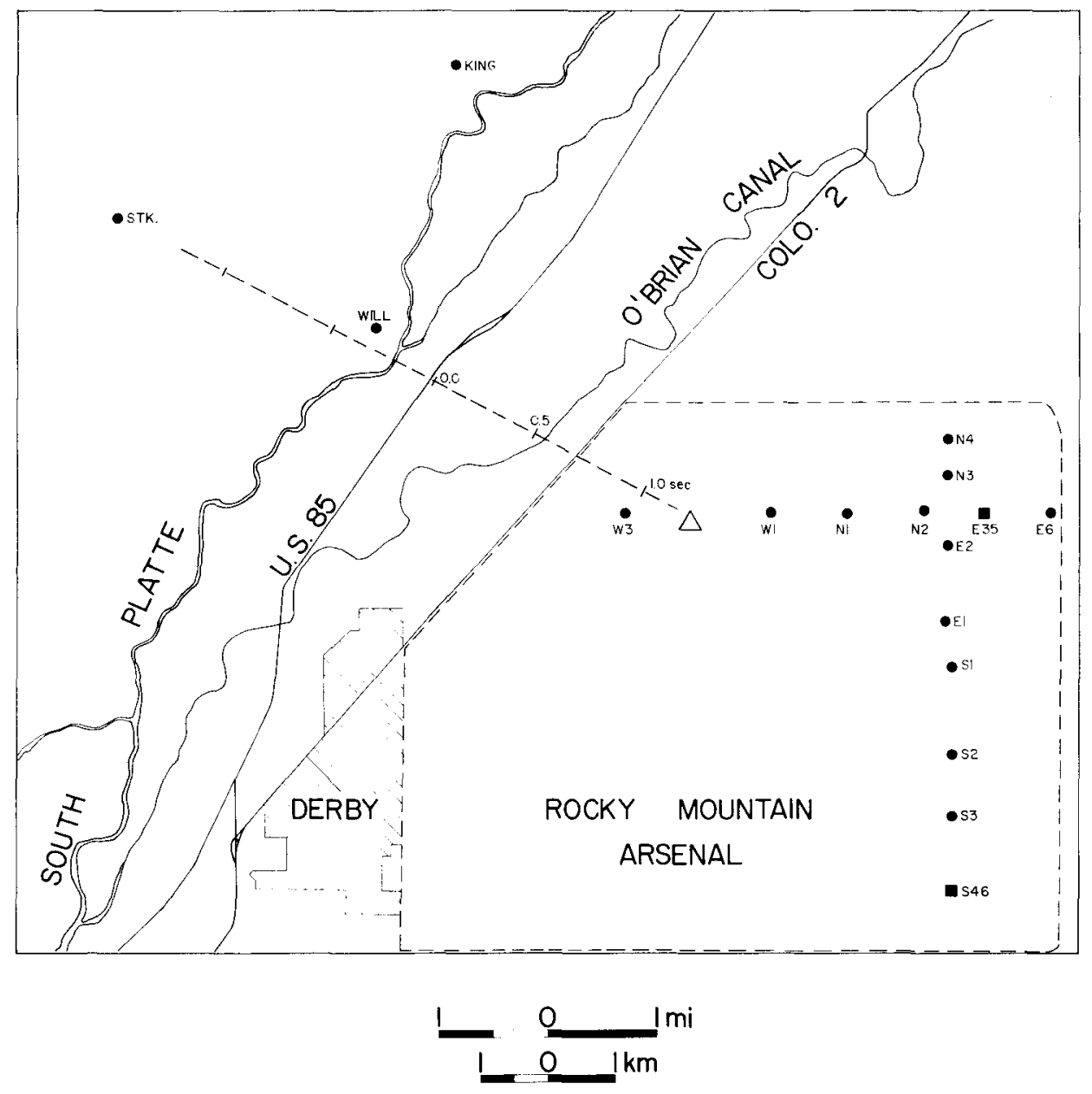

EXPLANATION

$\triangle$

ARSENAL WELL

RECORDING SITE SINGLE COMPONENT

RECORDING SITE THREE COMPONENT AFPROXIMATE FAULT TRACE 8 TIME SCALE WI-STK

Figure 1. Location map of seismic stations used during the test program showing the time difference for arrivals between stations STK and WT. 


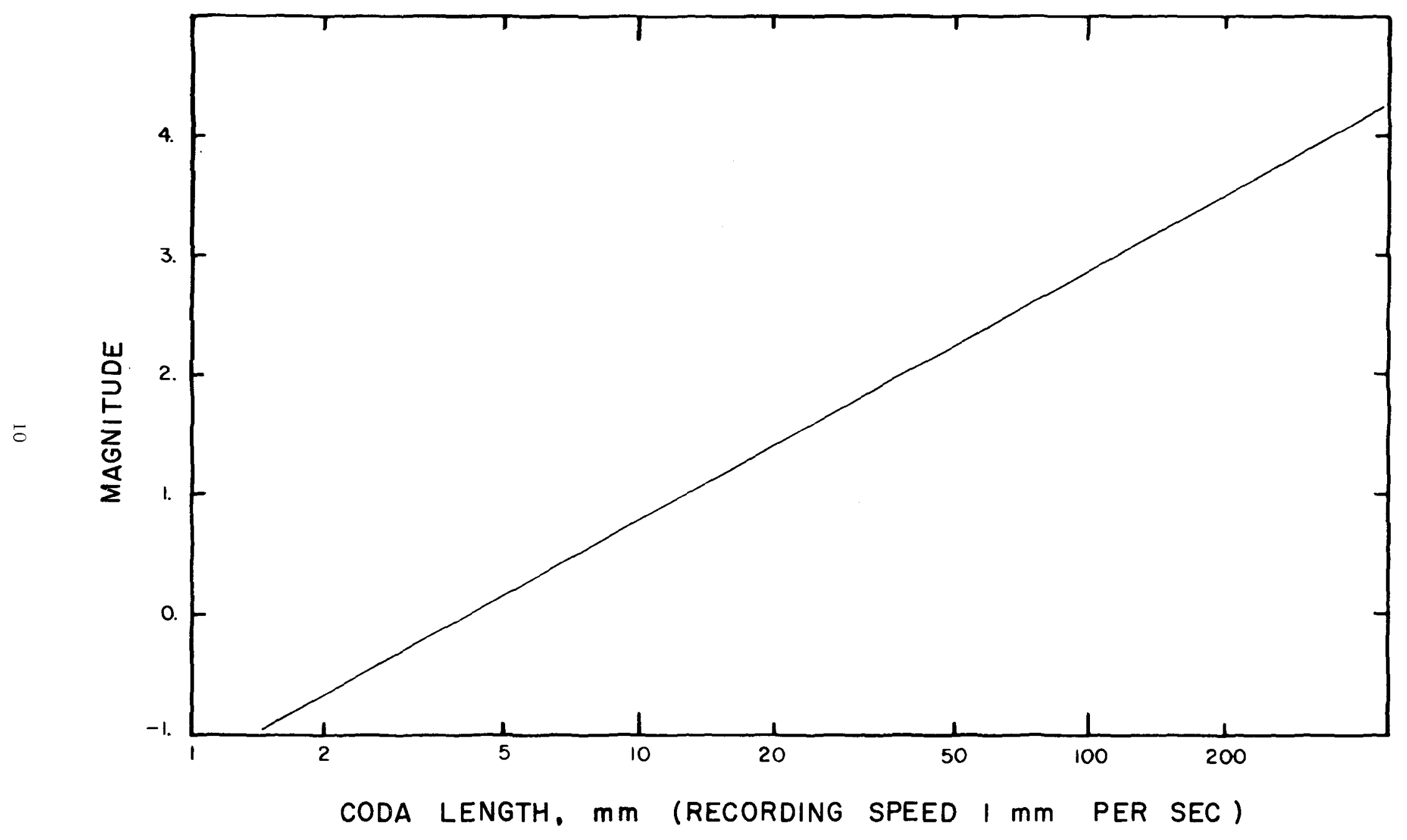

Figure 2. Empirical relationship between magnitude and coda. 


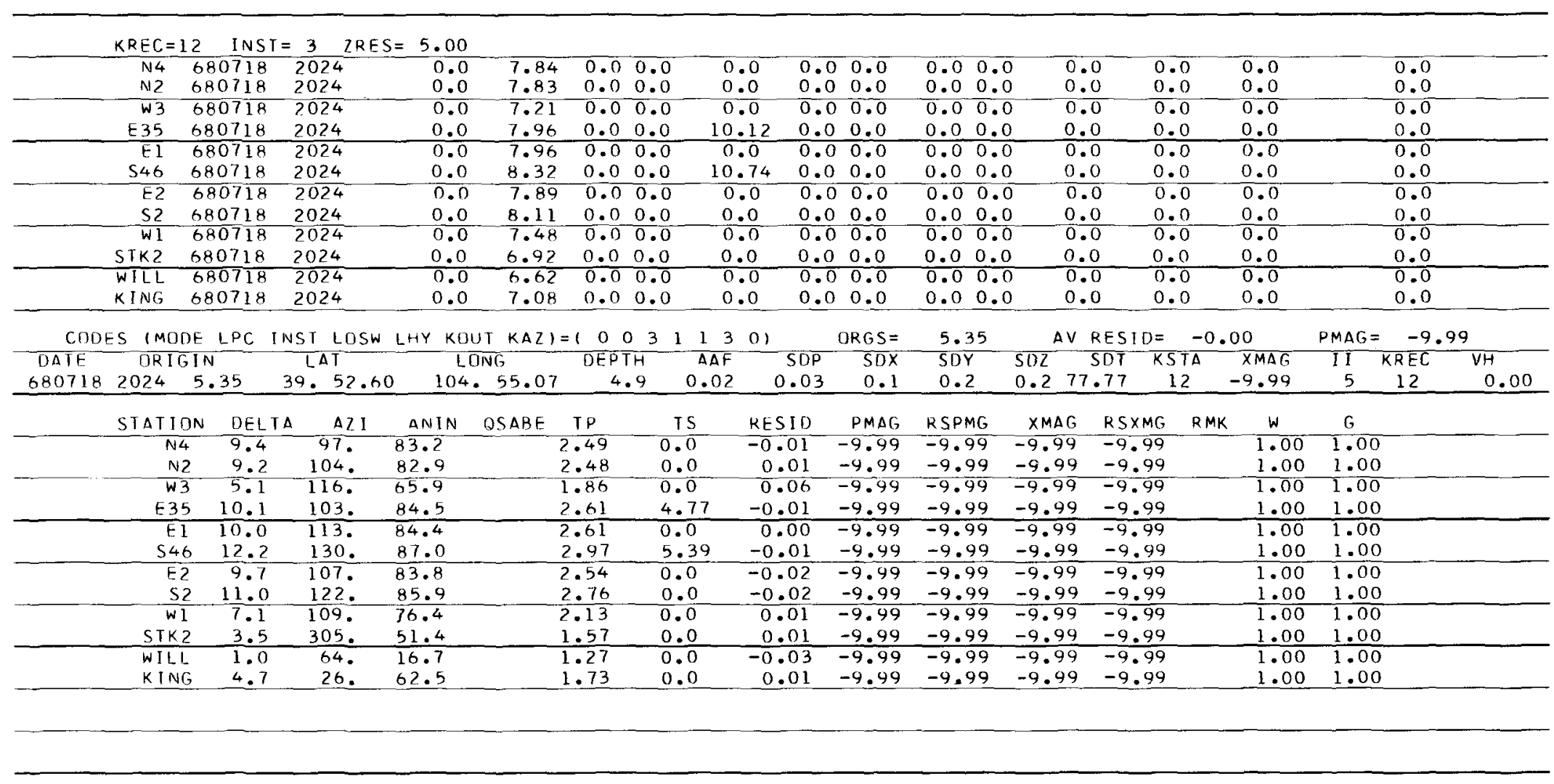

Figure 3. Computer output format for an earthquake occurring on July 18, 1968. 


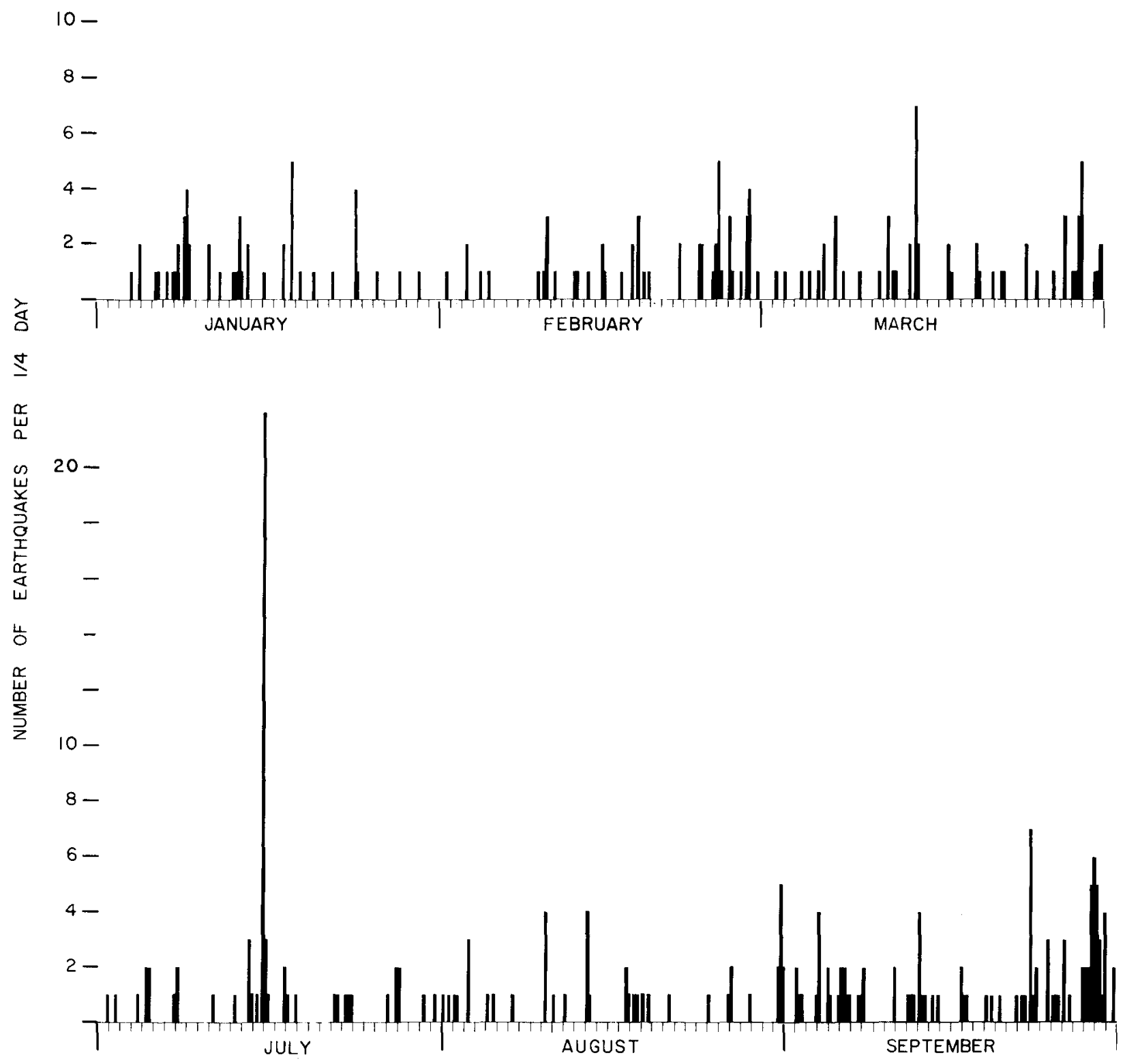

Figure 4. 1968 6-hour seismicity data. 

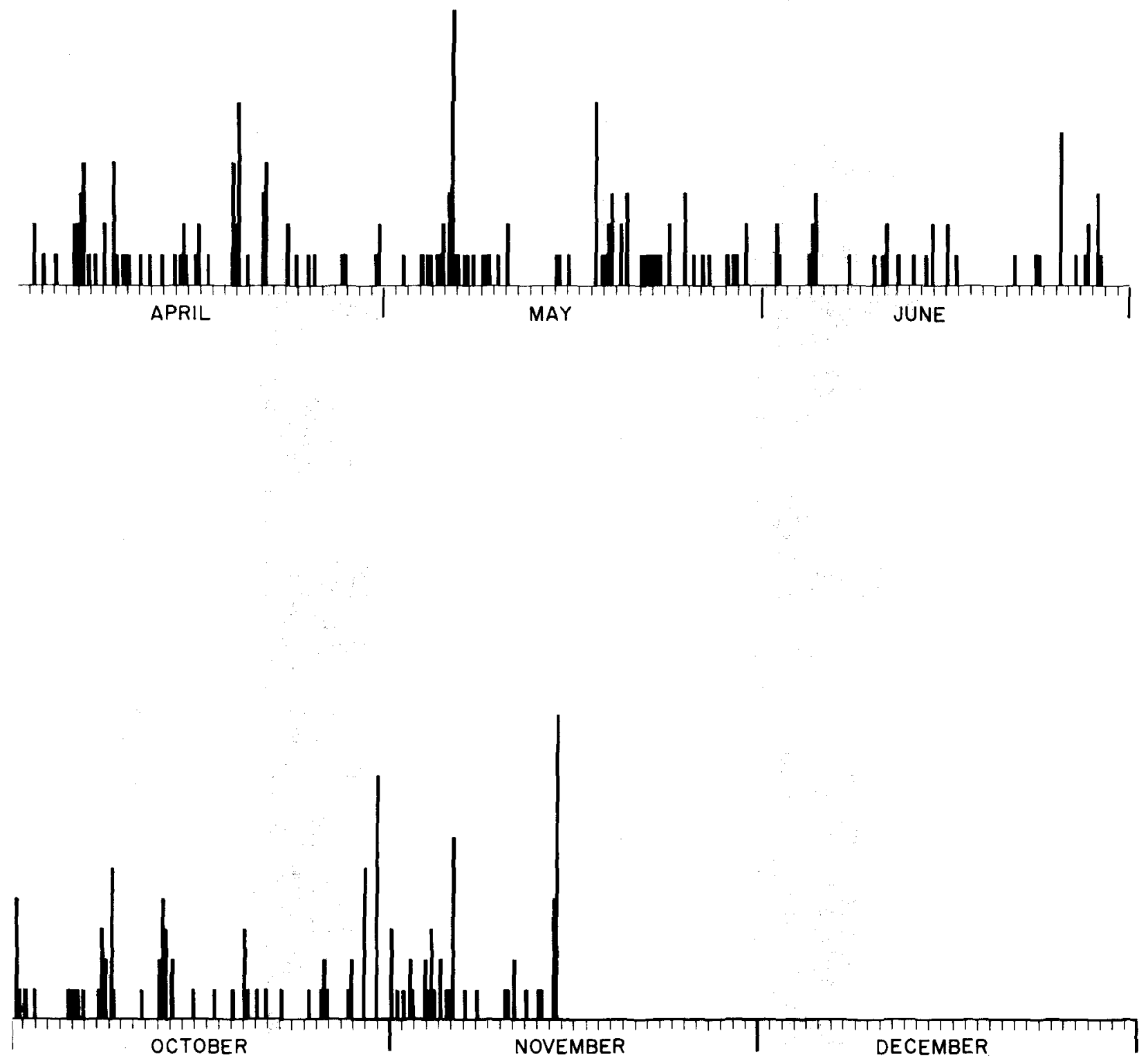

Figure 4.--Continued. 


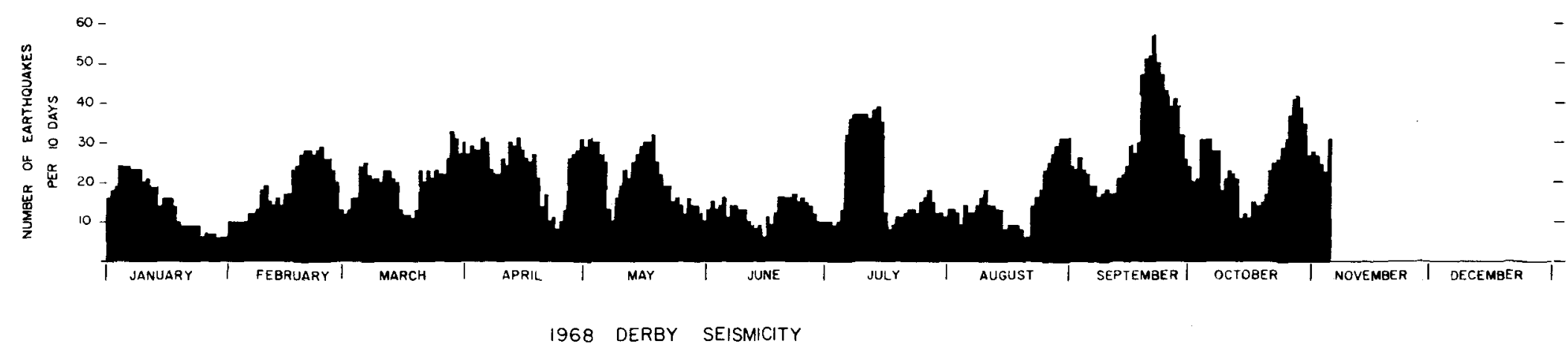

Figure 5. 1968 10-day average seismicity.

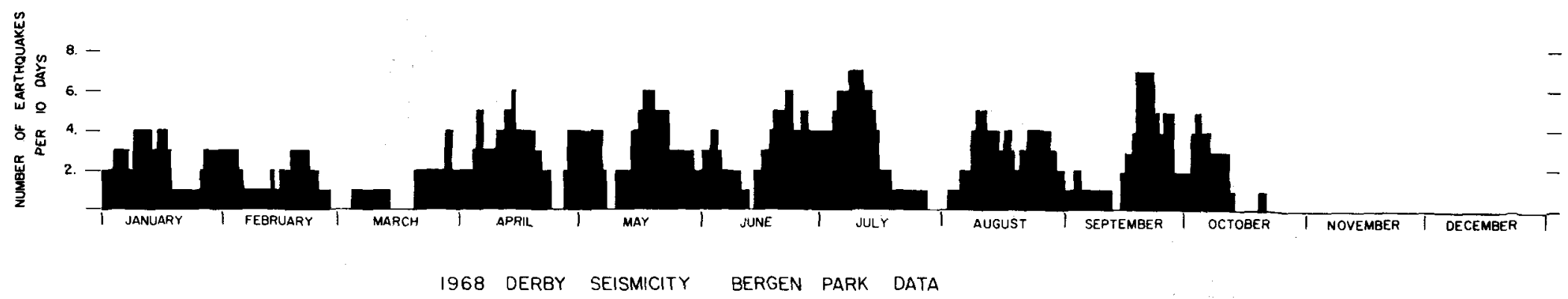

Figure 6. 1968 Bergen Park 10-day average seismicity. 


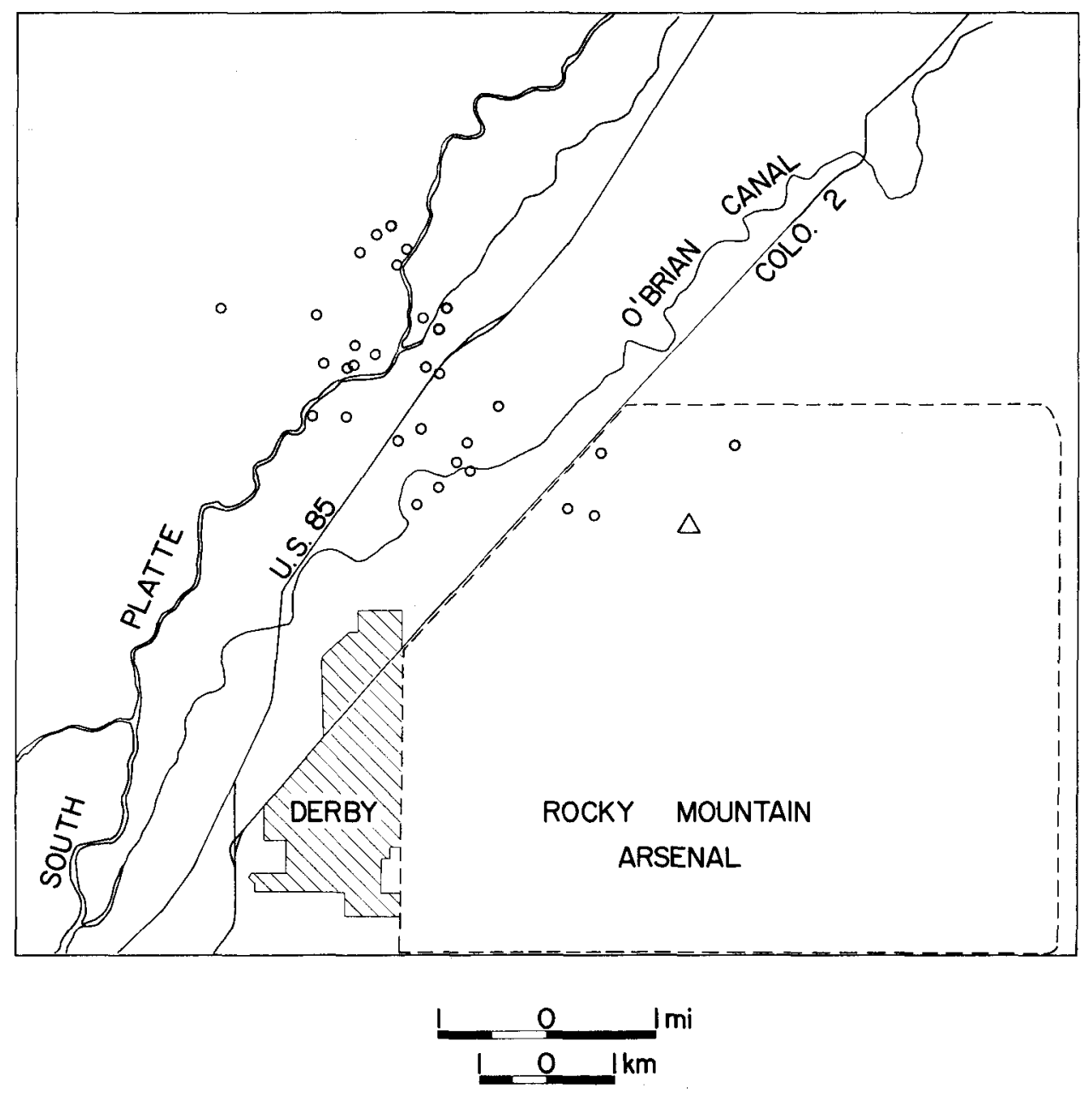

\section{EXPLANATION}

$\triangle$

ARSENAL WELL

EARTHQUAKE SEPTEMBER 1968

Figure 7. Map of earthquake epicenters for September 1968. 


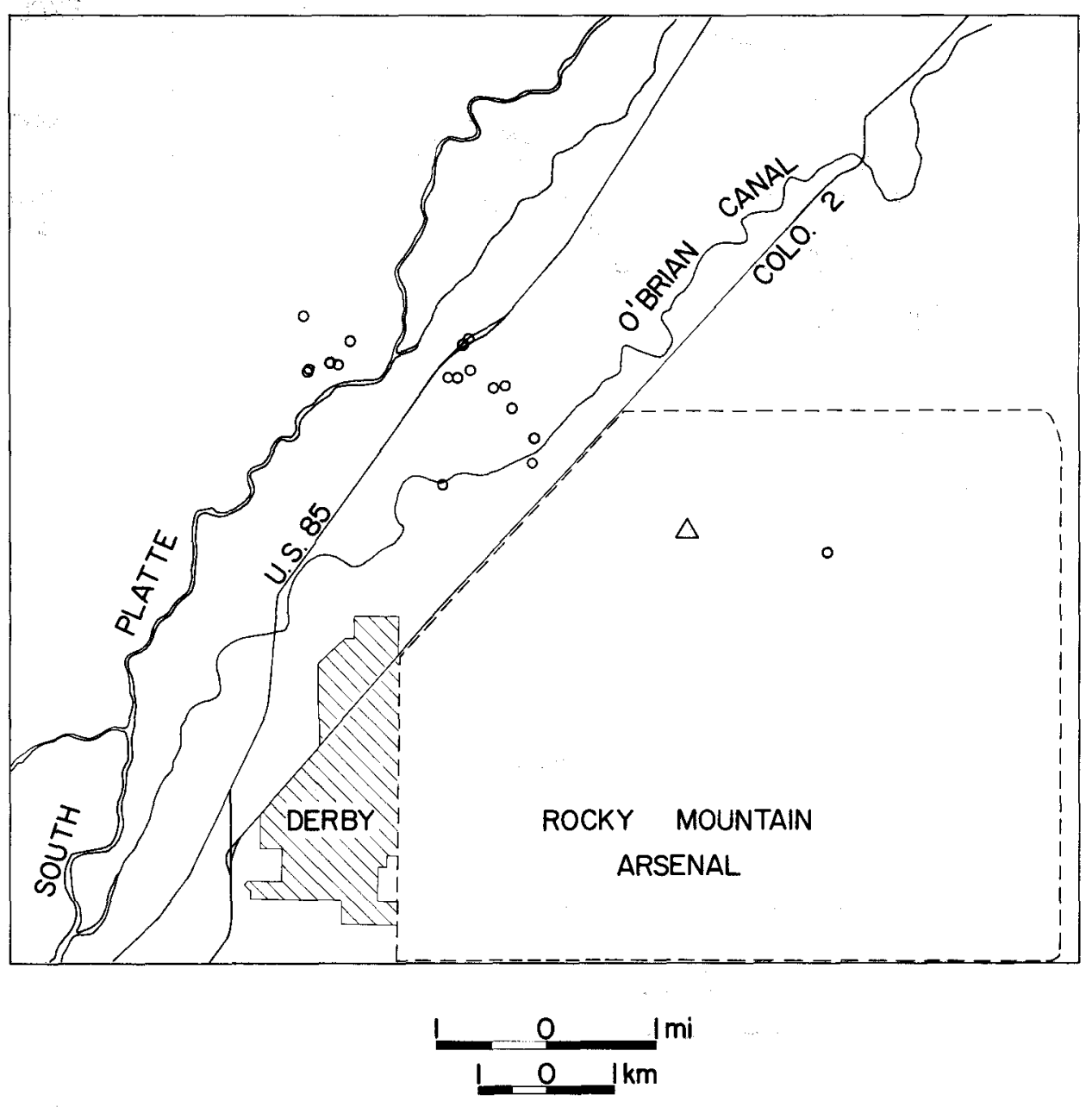

\section{EXPLANATION}

$\triangle$

ARSENAL WELL

EARTHQUAKE EPICENTERS

OCT.-NOV. 1968

Figure 8. Map of earthquake epicenters for October 1 to November 4, 1968. 

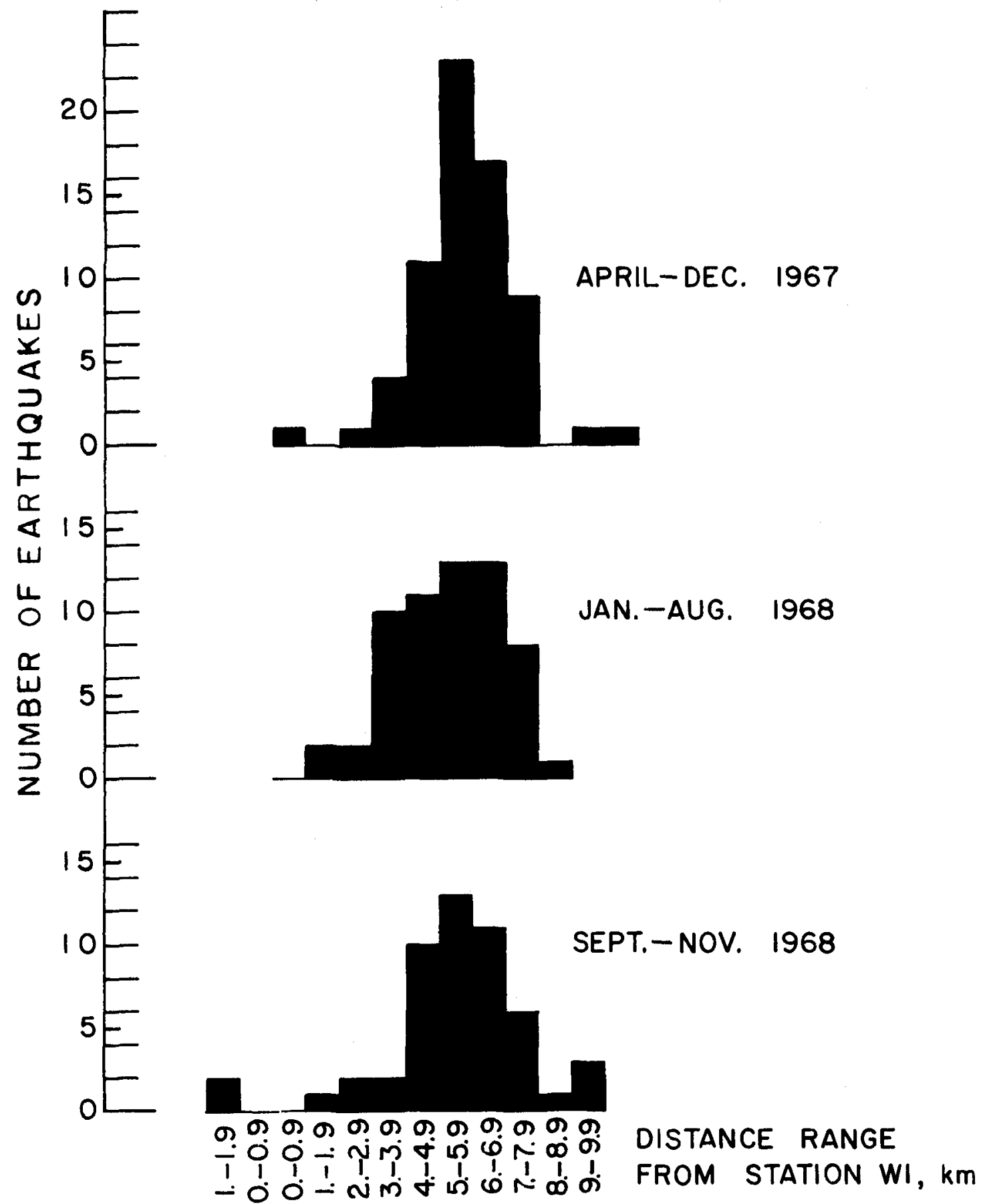
\begin{tabular}{l|l} 
EAST & WEST
\end{tabular}

Figure 9. Histogram showing distance of earthquakes from station W1. 


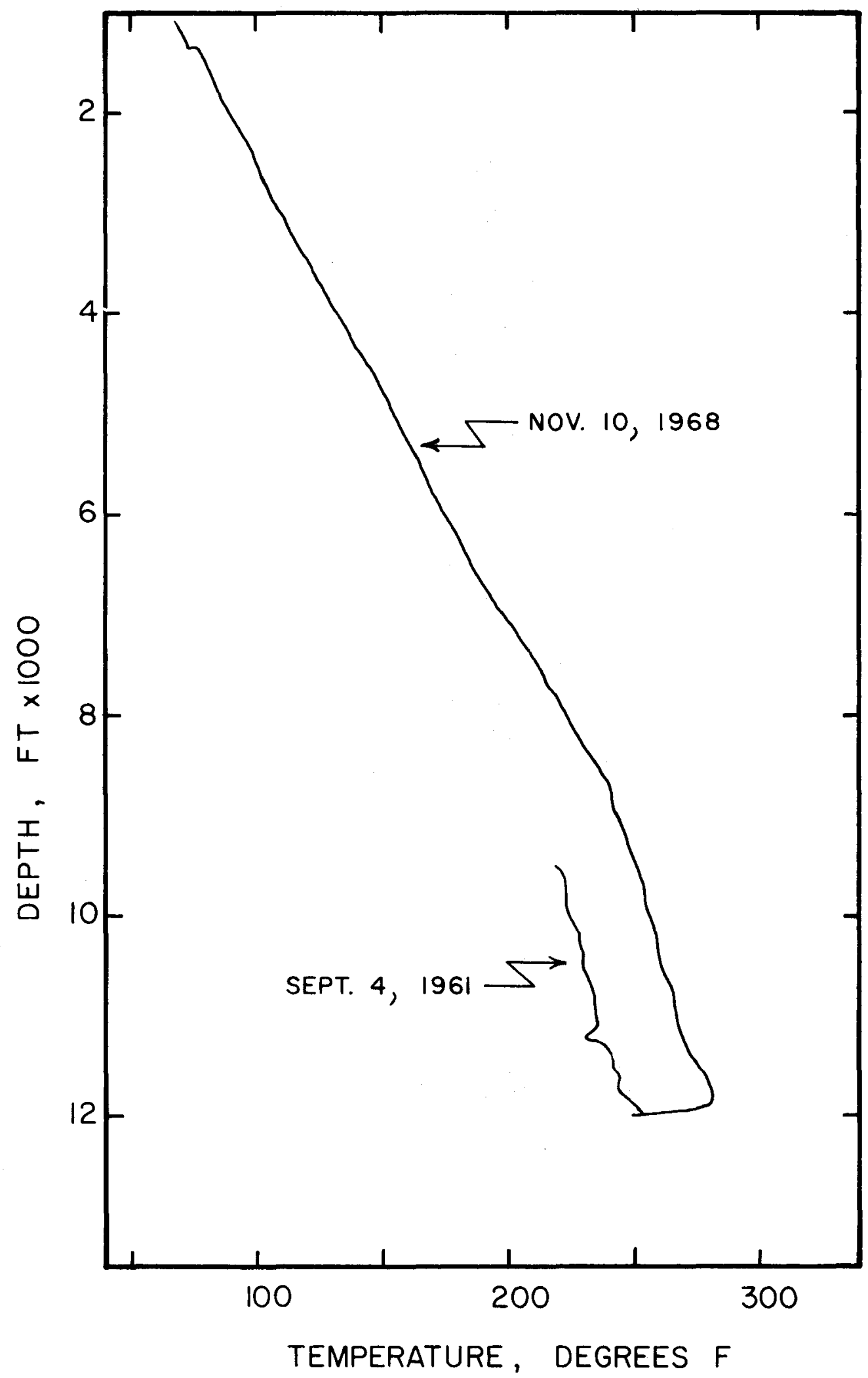

Figure 10. Temperature logs observed in the injection disposal wel1 on September 4, 1961 and November 10, 1968. 
Table 2.- Hypocenters for some Derby earthquakes occurring during 1967 and 1968

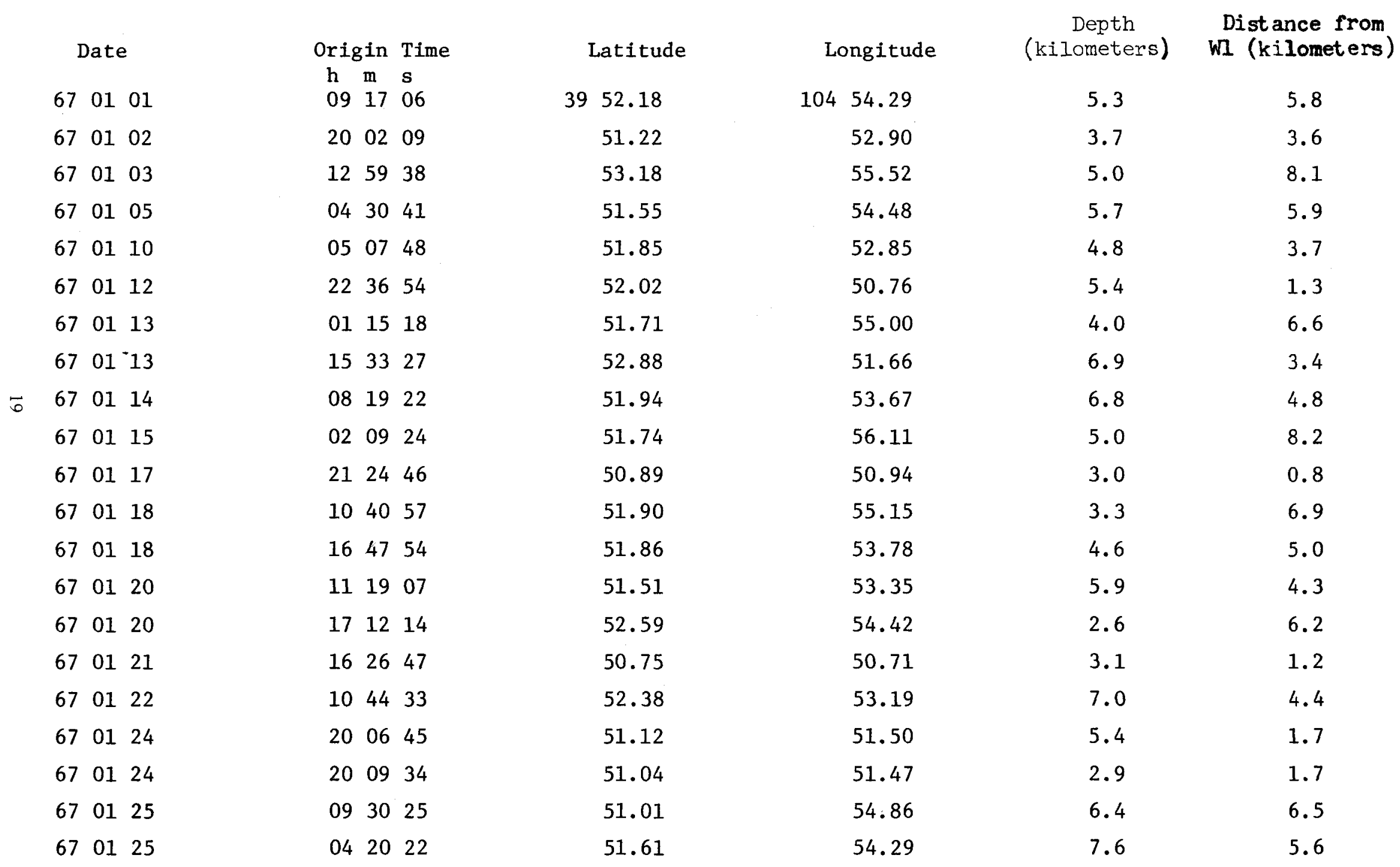


Table 2. - Hypocenters for some Derby earthquakes occurring during 1967 and 1968 -Continued

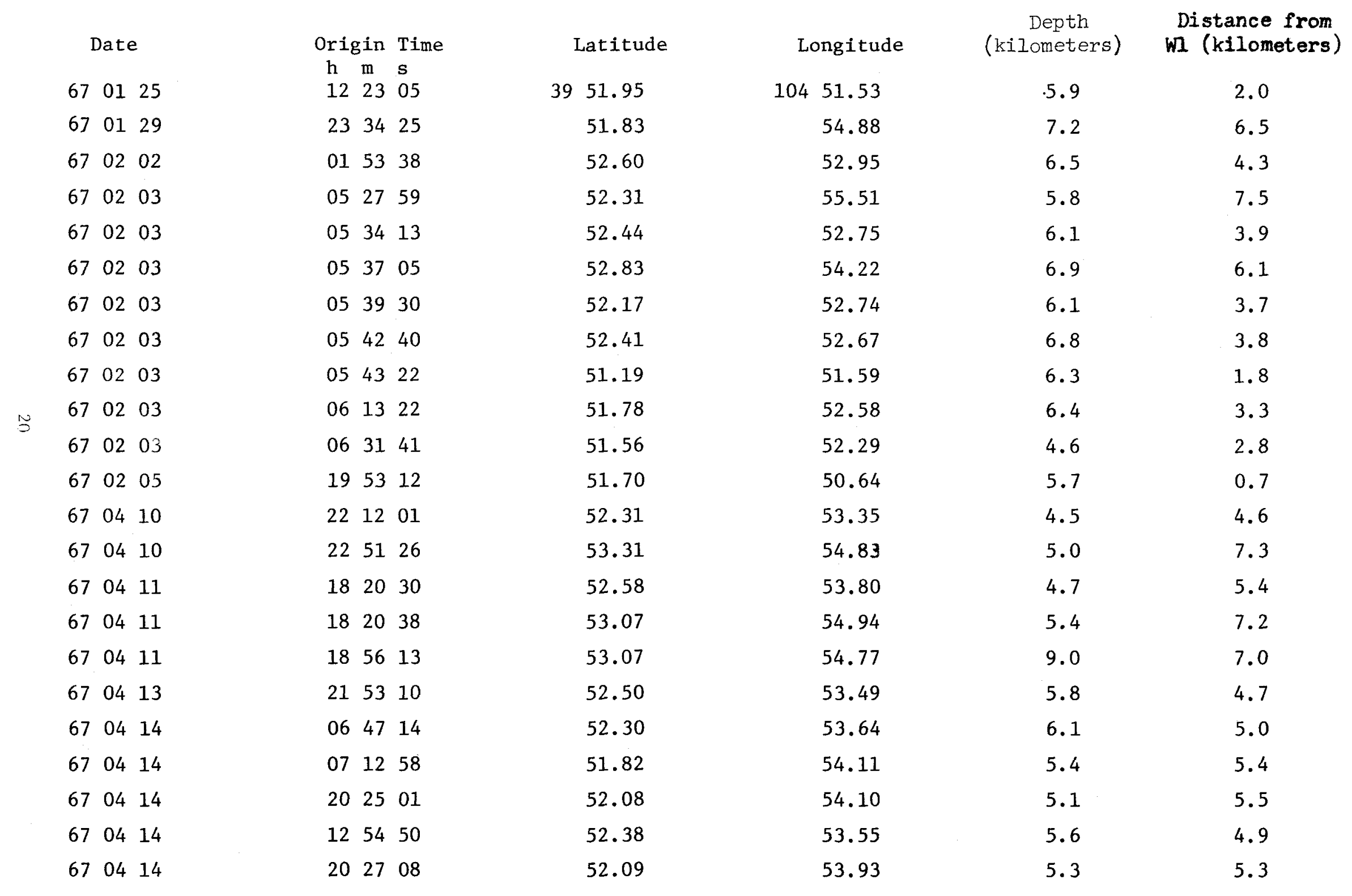


Table 2.-Hypocenters for some Derby earthquakes occurring during 1967 and 1968 - Continued

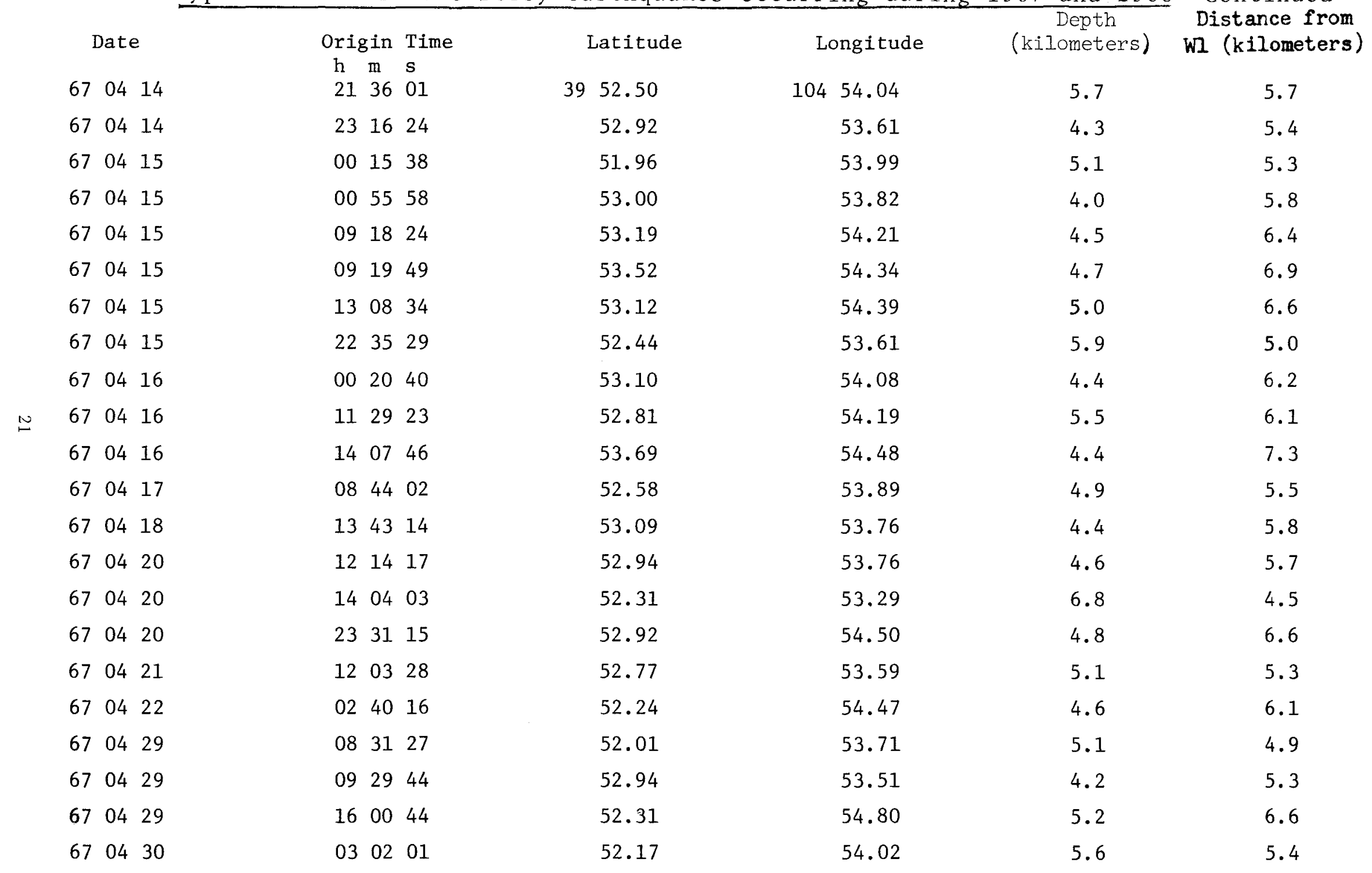


Table 2.- Hypocenters for some Derby earthquakes occurring during 1967 and 1968 - Continued

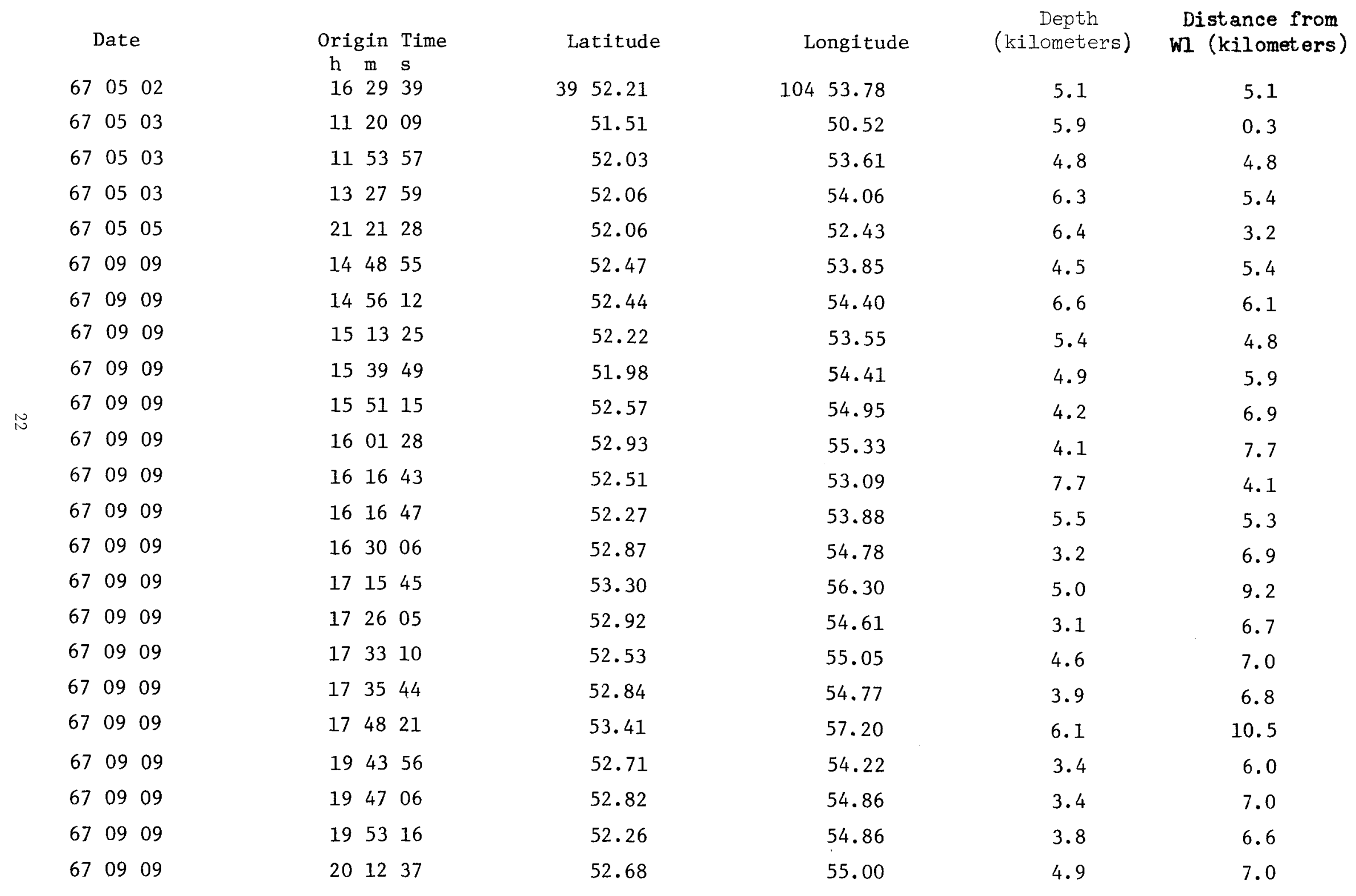


Table 2.-Hypocenters for some Derby earthquakes occurring during 1967 and 1968 - Continued

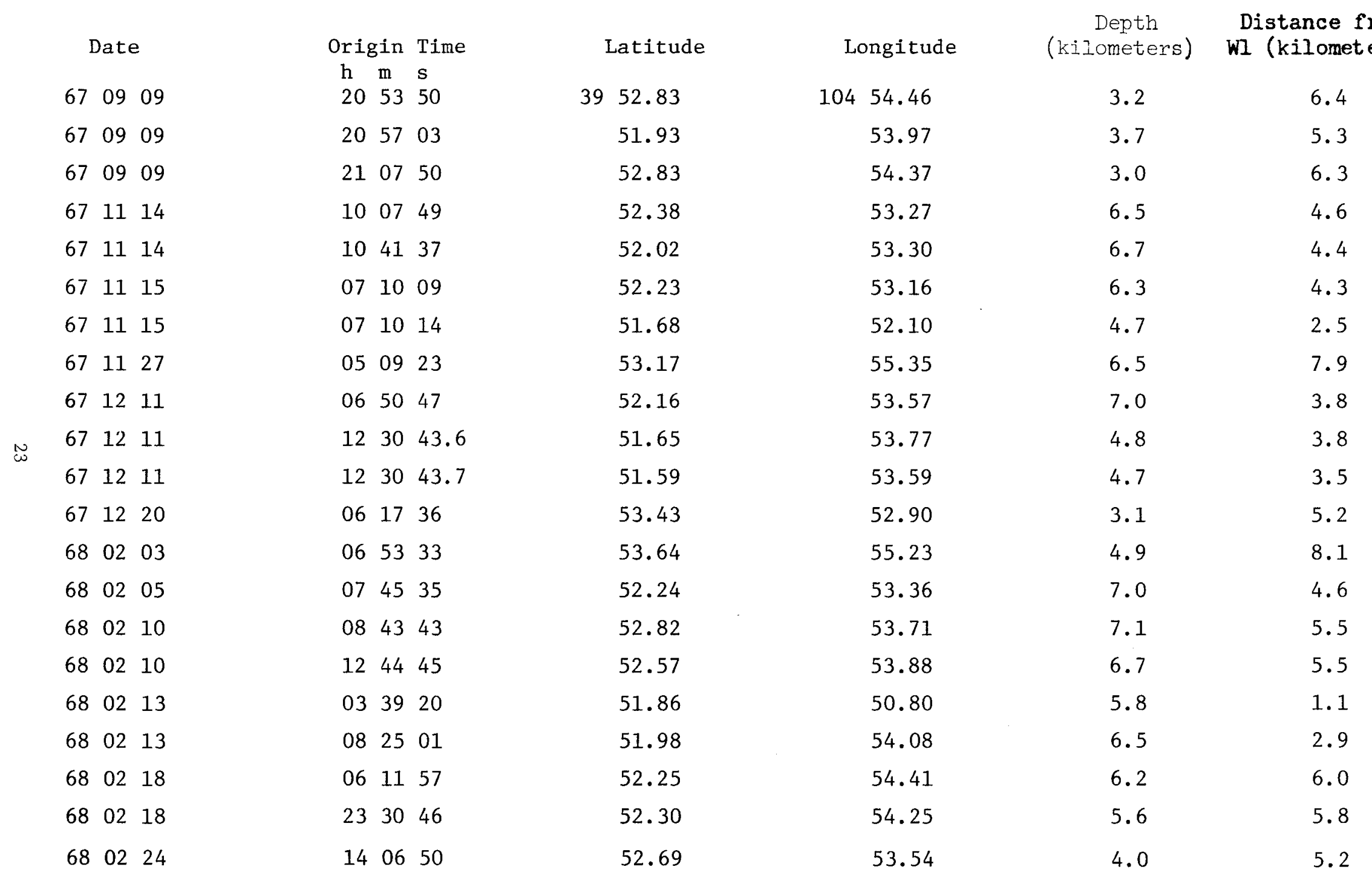


Table 2.- Hypocenters for some Derby earthquakes occurring during 1967 and 1968 - Continued

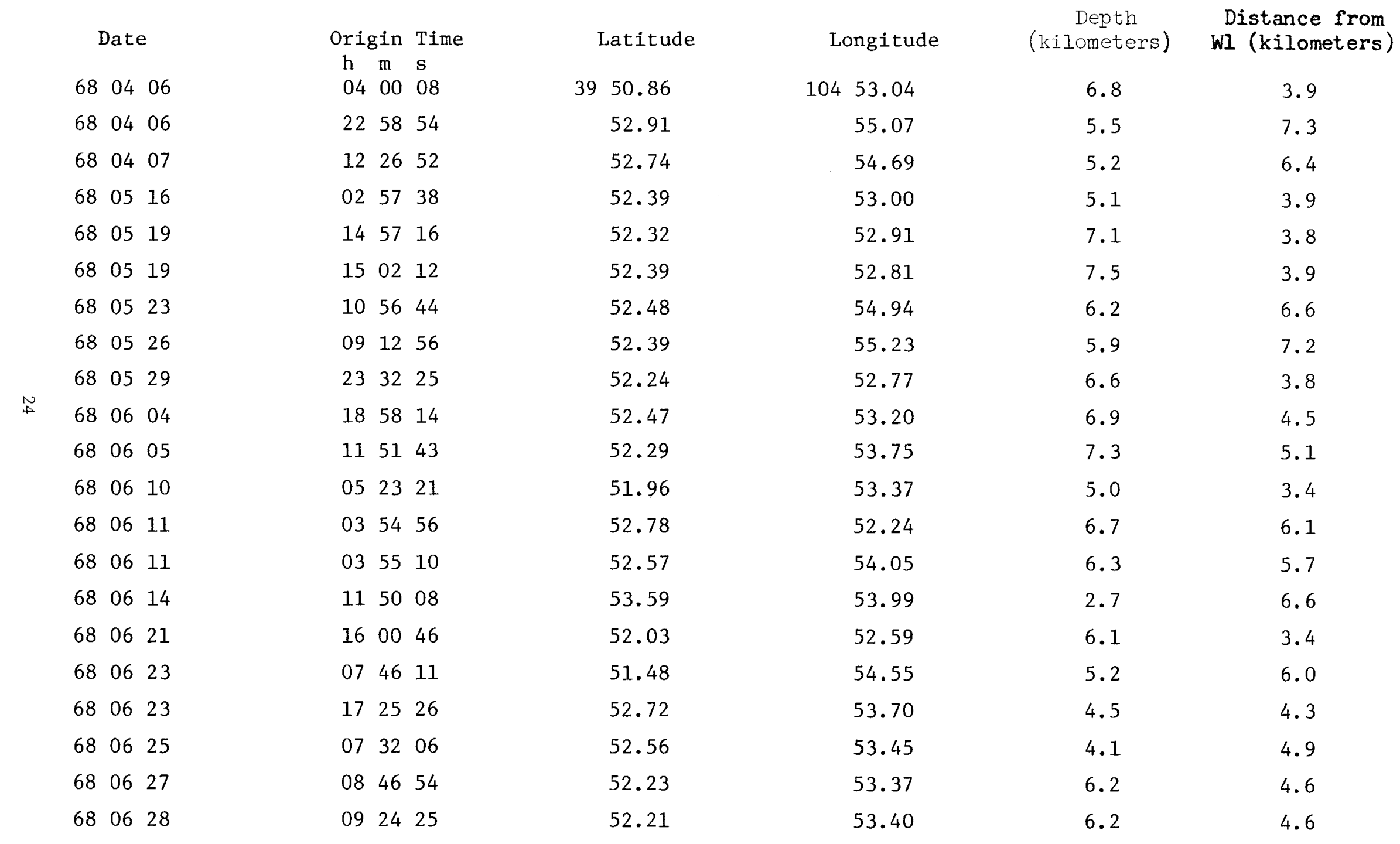


Table 2. - Hypocenters for some Derby earthquakes occurring during 1967 and 1968 -Continued

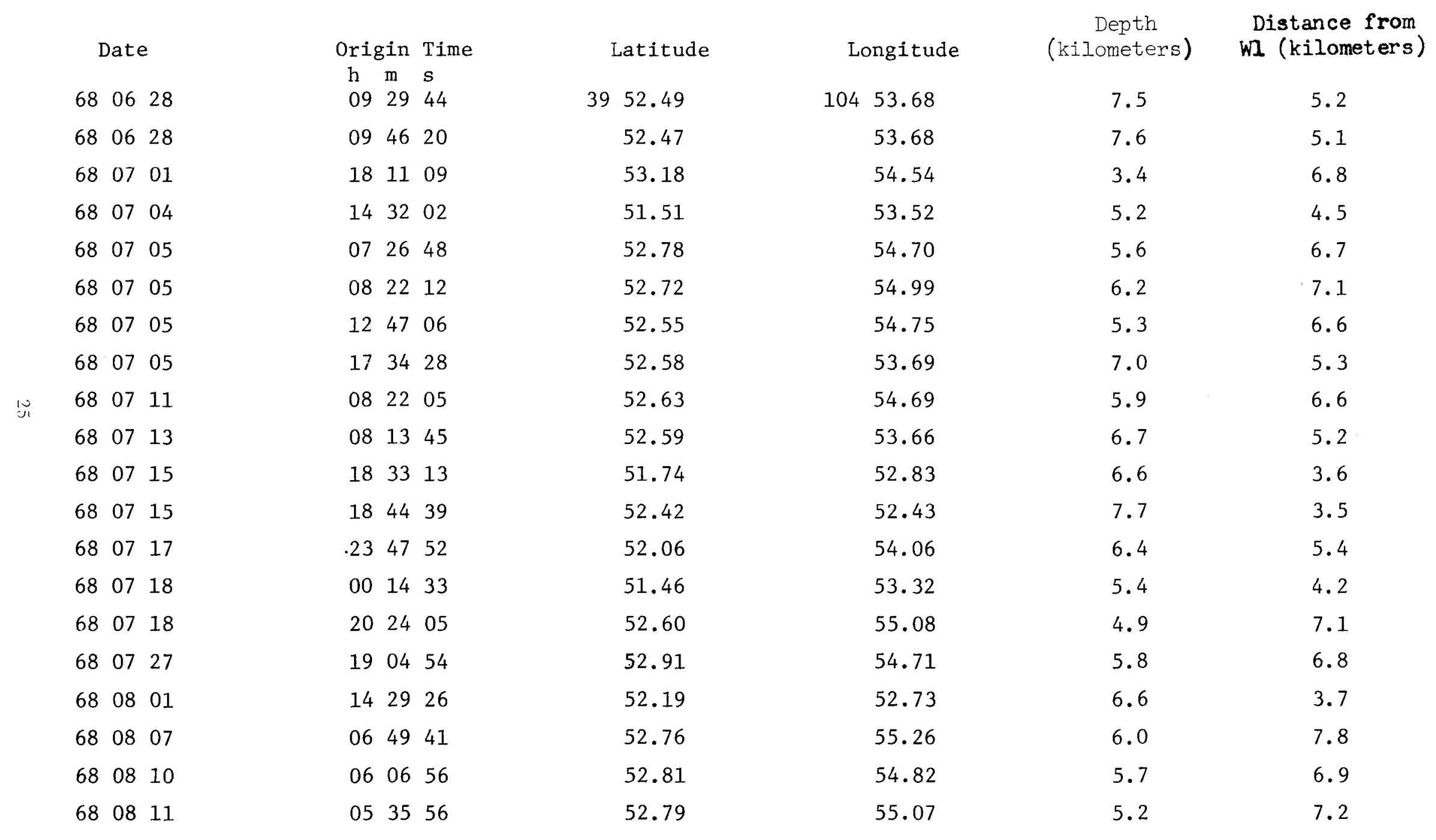


Table 2. - Hypocenters for some Derby earthquakes occurring during 1967 and 1968 - Continued

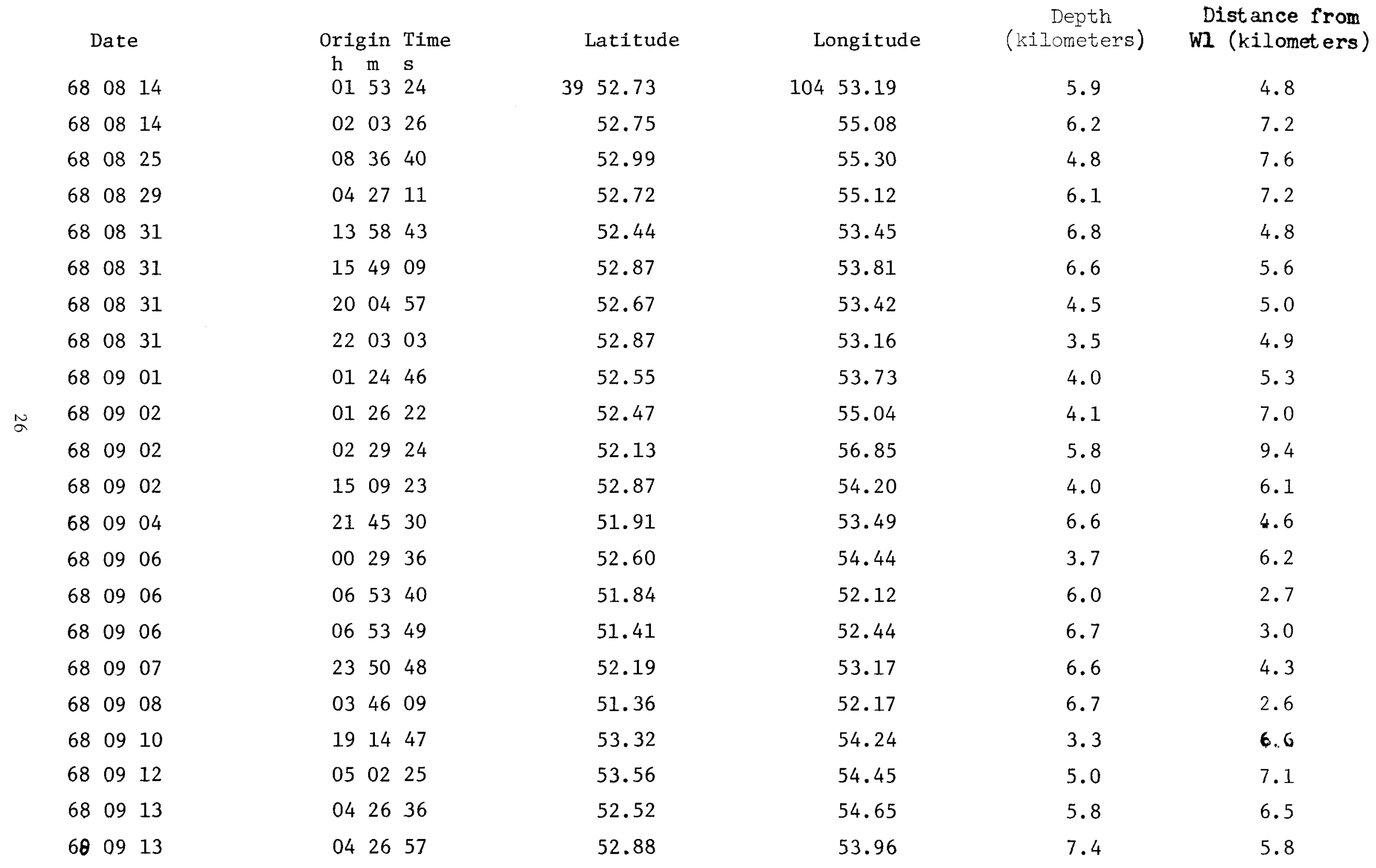


Table 2.- Hypocenters for some Derby earthquakes occurring during 1967 and 1968 - Continued

\begin{tabular}{|c|c|c|c|c|c|c|}
\hline Date & $\begin{array}{c}\text { Origin } \\
\mathrm{h} \mathrm{m}\end{array}$ & $\begin{array}{l}\text { Time } \\
\mathrm{s}\end{array}$ & Latitude & Longitude & $\begin{array}{c}\text { Depth } \\
\text { (kilometers) }\end{array}$ & $\begin{array}{l}\text { Distance from } \\
\text { WI (kilometers) }\end{array}$ \\
\hline $\begin{array}{lll}68 & 09 & 16\end{array}$ & $23 \quad 38$ & 31 & 3952.67 & 10454.66 & 5.5 & 6.6 \\
\hline $\begin{array}{lll}68 & 09 & 19\end{array}$ & 1548 & 35 & 51.92 & 50.73 & 5.2 & 1.1 \\
\hline $\begin{array}{lll}68 & 09 & 23\end{array}$ & 0035 & 40 & 52.80 & 53.79 & 7.0 & 5.6 \\
\hline $\begin{array}{lll}68 & 09 & 23\end{array}$ & 0110 & 28 & 52.50 & 53.92 & 7.0 & 5.5 \\
\hline $\begin{array}{lll}68 & 09 & 23\end{array}$ & 0236 & 53 & 52.44 & 53.77 & 7.0 & 5.2 \\
\hline $\begin{array}{lll}68 & 09 & 23\end{array}$ & $12 \quad 22$ & 48 & 51.92 & 54.20 & 4.8 & 5.6 \\
\hline $\begin{array}{lll}68 & 09 & 23\end{array}$ & 1444 & 56 & 51.42 & 54.00 & 5.1 & 5.2 \\
\hline $\begin{array}{lll}68 & 09 & 24\end{array}$ & 1451 & 27 & 53.41 & 54.61 & 5.9 & 7.1 \\
\hline $\begin{array}{lll}68 & 09 & 24\end{array}$ & 1452 & 18 & 53.63 & 54.30 & 5.7 & 9.7 \\
\hline $\begin{array}{lll}68 & 09 & 25\end{array}$ & $02 \quad 12$ & 00 & 53.45 & 54.14 & 4.8 & 6.6 \\
\hline $\begin{array}{lll}68 & 09 & 25\end{array}$ & $08 \quad 48$ & 02 & 52.94 & 56.03 & 6.7 & 8.4 \\
\hline $\begin{array}{lll}68 & 09 & 26\end{array}$ & 1226 & 11 & 52.02 & 53.95 & 5.6 & 5.3 \\
\hline $\begin{array}{lll}68 & 09 & 27\end{array}$ & 2047 & 01 & 52.11 & 55.08 & 5.6 & 6.9 \\
\hline $\begin{array}{lll}68 & 09 & 28\end{array}$ & 0343 & 54 & 51.69 & 53.45 & 5.7 & 4.4 \\
\hline $\begin{array}{lll}68 & 09 & 28\end{array}$ & $05 \quad 48$ & 36 & 51.56 & 53.76 & 5.8 & 4.9 \\
\hline $\begin{array}{lll}68 & 09 & 28\end{array}$ & 1346 & 26 & 51.76 & 53.59 & 5.8 & 4.7 \\
\hline $\begin{array}{lll}68 & 09 & 28\end{array}$ & 1653 & 32 & 52.48 & 54.72 & 5.6 & 6.5 \\
\hline $\begin{array}{lll}68 & 09 & 29\end{array}$ & 0038 & 34 & 52.97 & 53.71 & 4.3 & 5.6 \\
\hline $\begin{array}{lll}68 & 09 & 29\end{array}$ & 2222 & 47 & 52.90 & 55.05 & 5.9 & 7.3 \\
\hline $\begin{array}{lll}68 & 09 & 29\end{array}$ & 2223 & 01 & 52.10 & 54.72 & 4.4 & 6.4 \\
\hline $\begin{array}{lll}68 & 10 & 06\end{array}$ & 1951 & 35 & 52.96 & 55.14 & 5.4 & 7.4 \\
\hline
\end{tabular}


Table 2.-Hypocenters for some Derby earthquakes occurring during 1967 and 1968-Continued

\begin{tabular}{|c|c|c|c|c|c|c|c|}
\hline Date & Origin & Time & & Latitude & Longitude & $\begin{array}{c}\text { Depth } \\
\text { (kilometers) }\end{array}$ & $\begin{array}{c}\text { Distance from } \\
\text { WI (kilometers) }\end{array}$ \\
\hline $\begin{array}{lll}68 & 10 & 09\end{array}$ & $\begin{array}{ll}02 & 11\end{array}$ & 33 & 39 & 52.01 & 10452.76 & 6.9 & 3.6 \\
\hline $\begin{array}{lll}68 & 10 & 05\end{array}$ & 0608 & 41 & & 52.76 & 54.66 & 5.4 & 6.7 \\
\hline $\begin{array}{lll}68 & 10 & 11\end{array}$ & 1619 & 22 & & 52.54 & 53.43 & 6.4 & 4.9 \\
\hline $\begin{array}{lll}68 & 10 & 13\end{array}$ & 0347 & 22 & & 52.53 & 55.09 & 5.0 & 7.1 \\
\hline $\begin{array}{lll}68 & 10 & 13\end{array}$ & 1300 & 39 & & 52.48 & 53.55 & 7.2 & 5.0 \\
\hline $\begin{array}{lll}68 & 10 & 13\end{array}$ & 1301 & 14 & & 52.74 & 53.50 & 7.0 & 5.1 \\
\hline $\begin{array}{lll}68 & 10 & 14\end{array}$ & 0310 & 42 & & 52.40 & 53.20 & $7 . t$ & 4.5 \\
\hline $\begin{array}{lll}68 & 10 & 13\end{array}$ & 1048 & 13 & & 52.42 & 53.08 & 6.5 & 4.3 \\
\hline $\begin{array}{lll}68 & 10 & 17\end{array}$ & 1324 & 21 & & 52.24 & 53.01 & 6.6 & 4.1 \\
\hline $\begin{array}{lll}68 & 10 & 14\end{array}$ & 0501 & 12 & & 51.13 & 49.75 & 4.8 & 1.0 \\
\hline $\begin{array}{lll}68 & 10 & 30\end{array}$ & 1841 & 05 & & 52.79 & 53.44 & 4.3 & 5.1 \\
\hline $\begin{array}{lll}68 & 10 & 30\end{array}$ & 1845 & 20 & & 52.49 & 53.65 & $1 / 6$ & 5.1 \\
\hline $\begin{array}{lll}68 & 10 & 30\end{array}$ & 1827 & 07 & & 52.61 & 54.85 & 5.6 & 6.8 \\
\hline $68 \quad 1030$ & 1836 & 35 & & 52.59 & 54.78 & 5.1 & 6.7 \\
\hline $\begin{array}{lll}68 & 11 & 02\end{array}$ & 1429 & 02 & & 51.70 & 53.65 & 6.0 & 4.7 \\
\hline $\begin{array}{lll}68 & 11 & 0\end{array}$ & 1928 & 36 & & 52.56 & 55.07 & 6.7 & 6.7 \\
\hline $\begin{array}{lll}68 & 11 & 02\end{array}$ & 2147 & 13 & & 51.83 & 52.80 & 5.8 & 3.6 \\
\hline
\end{tabular}


Table 3.-Derby earthquakes from Sept. 1 to Nov. 15, 1968

\begin{tabular}{|c|c|c|c|c|}
\hline Date & & Time GMT & $\frac{\Delta t(W I-S T K)}{\underline{(\text { seconds })}}$ & Magnitude \\
\hline \multirow[t]{4}{*}{ September } & 2 & 0125 & .4 & 0.0 \\
\hline & & 0228 & .8 & 1.6 \\
\hline & & 0749 & -.1 & -0.3 \\
\hline & & 1509 & .5 & 0.0 \\
\hline September & 3 & 2208 & -.7 & -0.5 \\
\hline \multirow[t]{6}{*}{ September } & 4 & 0016 & -.4 & -1.0 \\
\hline & & 0115 & .4 & -0.1 \\
\hline & & 0346 & .4 & 0.3 \\
\hline & & 0456 & .3 & -0.2 \\
\hline & & 1900 & .3 & -0.1 \\
\hline & & 2145 & -.2 & 1.4 \\
\hline \multirow[t]{2}{*}{ September } & 5 & 0546 & .4 & -0.4 \\
\hline & & 2349 & .1 & -0.3 \\
\hline \multirow[t]{5}{*}{ September } & 6 & 0029 & .2 & 0.3 \\
\hline & & 0211 & .4 & -0.4 \\
\hline & & 0653 & -.7 & 0.3 \\
\hline & & 0653 & -.7 & -0.1 \\
\hline & & 2325 & noisy trace & -0.6 \\
\hline \multirow[t]{2}{*}{ September } & 7 & 1604 & 0.0 & -0.5 \\
\hline & & 2350 & .5 & 0.5 \\
\hline \multirow[t]{2}{*}{ September } & 8 & 0346 & -.5 & 0.1 \\
\hline & & 0358 & .5 & -0.5 \\
\hline \multirow[t]{2}{*}{ September } & 10 & 1914 & .3 & -0.1 \\
\hline & & 2009 & .2 & 0.3 \\
\hline \multirow[t]{2}{*}{ September } & 12 & 0503 & .4 & 2.0 \\
\hline & & 1658 & 0.0 & -0.6 \\
\hline \multirow[t]{6}{*}{ September } & 13 & 0207 & noisy trace & -0.5 \\
\hline & & 0355 & .5 & -0.7 \\
\hline & & 0426 & -.5 & 0.5 \\
\hline & & 0426 & .7 & 0.7 \\
\hline & & 0720 & .1 & -0.2 \\
\hline & & 1424 & .1 & -0.5 \\
\hline
\end{tabular}


Table 3.-Derby earthquakes from Sept. 1 to Nov. 15, 1968-Continued

\section{Date}

September 14

September 16

September 17

September 19

September 20

September 21

September 22

September 23

\section{Septenber 23}

(1)

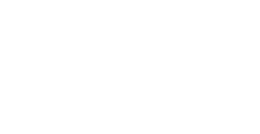

September 24

September 25

September 26
Time GMT

0947

2328

2257

2338

0005

0614

0452

1548

1003

2016

0720

1523

0035

0109

0111

0112

0112

0112

0236

0826

1222

1444

1451

1452

1506

0212

0848

1244

0104

0113

0211

1.226
$\frac{\Delta t(\mathrm{Wl}-\mathrm{STK})}{(\text { seconds })}$

.1

Magnitude

$-0.3$

$-.4$

$-0.7$

.3

$-0.2$

.5

0.3

noisy trace

$-0.3$

.1

$-0.3$

.3

$-0.5$

$-1.6$

0.5

noisy trace

$-0.7$

.5

$-0.7$

.5

$-0.7$

.8

$-0.2$

$-.1$

0.2

0.0

0.7

$-.4$

$-0.5$

$-.1$

$-0.4$

$-.4$

$-1.0$

$-.6$

0.0

.1

0.3

0.0

$-0.3$

0.0

0.1

$-.3$

0.2

.7

2.3

.2

1.0

1.7

1.6

.5

0.8

.4

0.0

0.0

$-0.2$

$-.2$

$-0.7$

$-.2$

$-0.3$

0.0

0.5 
Tab1e 3.-Derby earthquakes from Sept. 1 to Nov. 15, 1968-Continued

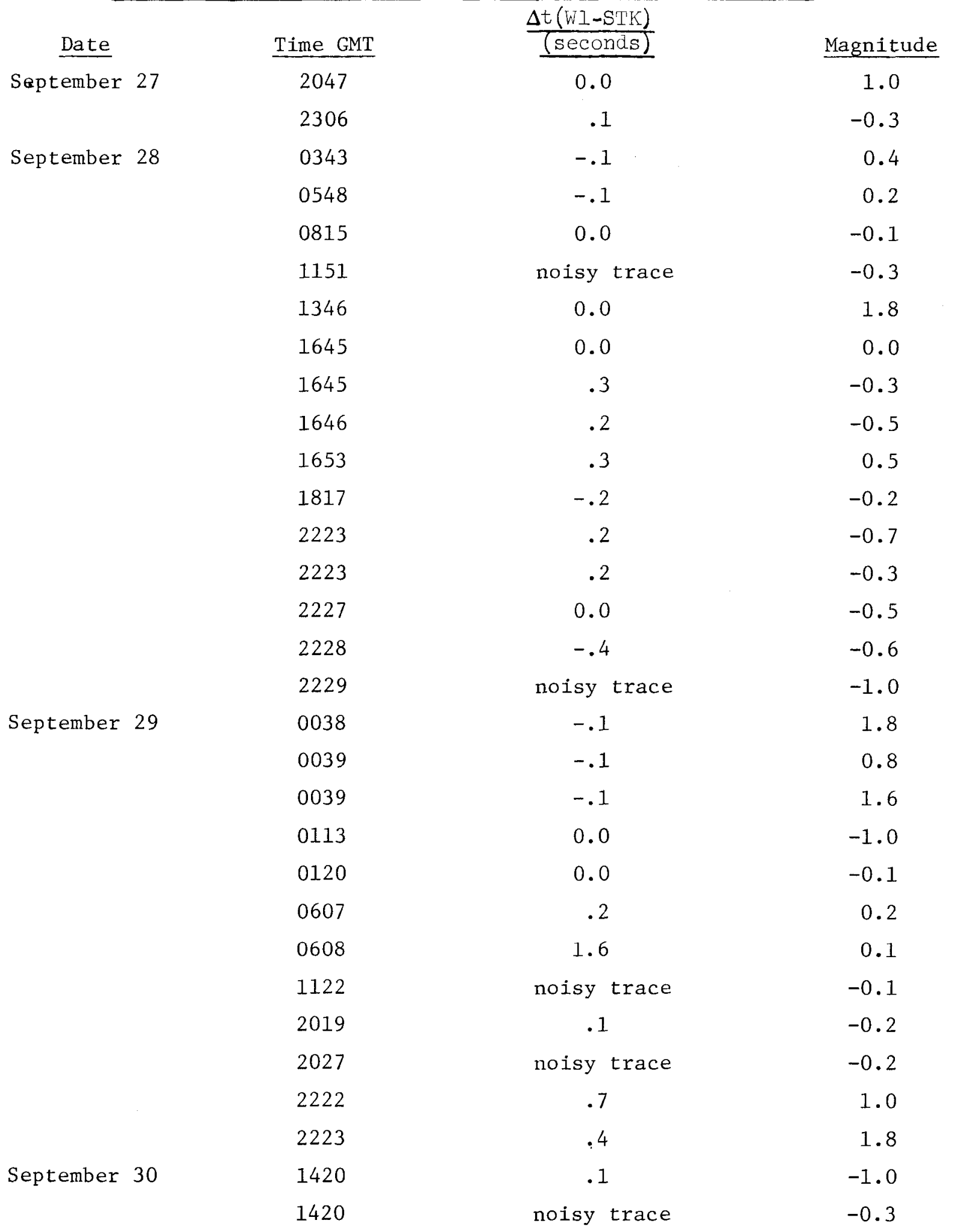


Table 3.-Derby earthquakes from Sept. 1 to Nov. 15, 1968-Continued

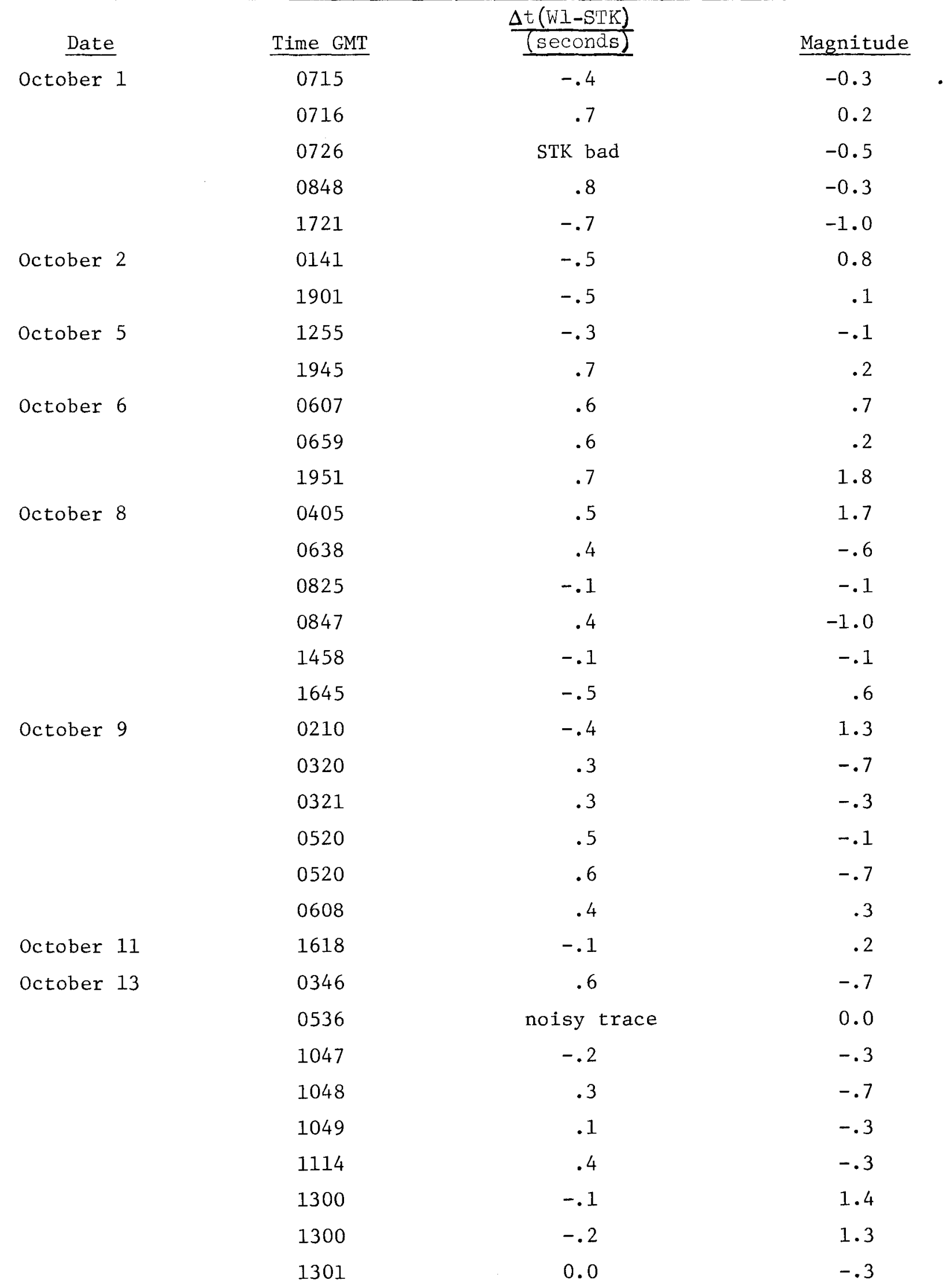


Table 3.-Derby earthquakes from Sept. 1 to Nov. 15, 1968-Continued

\begin{tabular}{|c|c|c|c|}
\hline Date & Time GMT & $\frac{\Delta t(W I-S T K)}{(\sec o n d s)}$ & Magnitude \\
\hline \multirow[t]{2}{*}{ October 14} & 0310 & -.3 & 2.0 \\
\hline & 0500 & -1.5 & .5 \\
\hline October 15 & 2214 & -.1 & .6 \\
\hline October 17 & 1323 & -.1 & .7 \\
\hline October 19 & 0359 & .5 & -0.1 \\
\hline \multirow[t]{4}{*}{ October 20} & 0236 & .5 & -.2 \\
\hline & 0416 & -.5 & -.3 \\
\hline & 0416 & -.5 & -.6 \\
\hline & 0906 & -.5 & .1 \\
\hline \multirow[t]{2}{*}{ October 21} & 0524 & -.4 & -.7 \\
\hline & 1814 & 1.8 & .3 \\
\hline October 23 & 0405 & 1.1 & 2.0 \\
\hline October 25 & 0628 & 1.0 & -1.0 \\
\hline \multirow[t]{4}{*}{ October 26} & 0916 & -.6 & -.2 \\
\hline & 1345 & .3 & -1.0 \\
\hline & 1537 & 0.0 & -.4 \\
\hline & 2359 & .2 & -1.0 \\
\hline \multirow[t]{3}{*}{ October 28} & 1317 & .1 & .6 \\
\hline & 2115 & .2 & -1.0 \\
\hline & 2215 & 0.0 & .3 \\
\hline \multirow[t]{5}{*}{ October 29} & 2258 & .5 & -.2 \\
\hline & 2258 & .2 & .1 \\
\hline & 2259 & .7 & -.1 \\
\hline & 2259 & .6 & -.1 \\
\hline & 2300 & .6 & -.6 \\
\hline \multirow[t]{8}{*}{ October 30} & 1826 & noisy trace & .7 \\
\hline & 1835 & .5 & 1.8 \\
\hline & 1838 & .1 & -.7 \\
\hline & 1838 & .2 & -.1 \\
\hline & 1844 & -.3 & .6 \\
\hline & 1846 & 0.0 & -.1 \\
\hline & 1846 & .3 & -1.0 \\
\hline & 1846 & 0.0 & .9 \\
\hline
\end{tabular}


Table 3.-Derby earthquakes from Sept. 1 to Nov. 15, 1968-Continued

\begin{tabular}{|c|c|c|c|}
\hline Date & Time GMT & $\frac{\Delta t(\mathrm{WL}-\mathrm{STK})}{(\mathrm{seconds})}$ & Magnitude \\
\hline \multirow[t]{4}{*}{ November 1} & 0303 & noisy trace & .4 \\
\hline & 0504 & -.4 & -.4 \\
\hline & 0515 & .5 & -.7 \\
\hline & 1426 & .6 & -.1 \\
\hline \multirow[t]{4}{*}{ November 2} & 0523 & .5 & -.3 \\
\hline & 1428 & -.6 & 3.1 \\
\hline & 1432 & -.5 & -1.0 \\
\hline & 2146 & -.4 & -.6 \\
\hline \multirow[t]{2}{*}{ November 3} & 1827 & .4 & .3 \\
\hline & 1828 & .5 & -1.0 \\
\hline \multirow[t]{5}{*}{ November 4} & 0006 & .2 & -1.0 \\
\hline & 0825 & -.2 & -.7 \\
\hline & 0834 & .5 & .5 \\
\hline & 1150 & .1 & -.5 \\
\hline & 1431 & .6 & -.7 \\
\hline \multirow[t]{4}{*}{ November 5} & 0418 & 0.0 & -.2 \\
\hline & 0423 & 0.0 & -.4 \\
\hline & 1730 & -.1 & .9 \\
\hline & 1950 & .2 & 1.7 \\
\hline \multirow[t]{6}{*}{ November 6} & 0002 & -.6 & .9 \\
\hline & 0020 & 0.0 & .2 \\
\hline & 0031 & noisy trace & -.7 \\
\hline & 0346 & -.2 & -.4 \\
\hline & 0452 & .4 & -.7 \\
\hline & 0507 & .7 & -.1 \\
\hline November 7 & 0447 & .6 & -.1 \\
\hline November 8 & 0424 & .6 & -.1 \\
\hline \multirow[t]{2}{*}{ November 10} & 0949 & -.3 & -.8 \\
\hline & 1341 & -.2 & -.1 \\
\hline \multirow[t]{2}{*}{ November 11} & 0008 & .4 & 1.4 \\
\hline & 0338 & -1.3 & -.8 \\
\hline November 12 & 0526 & .3 & .8 \\
\hline
\end{tabular}


Table 3.-Derby earthquakes from Sept. 1 to Nov. 15, 1968 -Continued Date $\frac{\Delta t(\mathrm{WI}-\mathrm{STK})}{\underline{\text { seconds })}}$

Magnitude

$\begin{array}{rrrr}\text { November 13 } & 0430 & -- & -0.5 \\ \text { November 14 } & 1041 & -- & -0.5 \\ & 0905 & -- & -.1 \\ 1136 & -- & .5 \\ 1142 & -- & -.7 \\ 1143 & -- & -.7 \\ 1214 & -- & -.7 \\ 1223 & -- & -.5 \\ 1223 & -- & -.5 \\ 1224 & -- & 1.4 \\ 1230 & -- & .7 \\ 1231 & -- & -.7 \\ 1234 & -- & .1 \\ 1235 & -- & -1.0 \\ 1240 & -- & -.7 \\ 1342 & -.8 & -8\end{array}$


